Article

\title{
Antiviral Activities of Compounds Isolated from Pinus densiflora (Pine Tree) against the Influenza A Virus
}

\author{
Thi Kim Quy Ha ${ }^{1,2,+}$, Ba Wool Lee ${ }^{1,+} \oplus$, Ngoc Hieu Nguyen ${ }^{1}$, Hyo Moon Cho ${ }^{1}$, \\ Thamizhiniyan Venkatesan ${ }^{1}$, Thi Phuong Doan ${ }^{1}$, Eunhee $\mathrm{Kim}^{3}$ and Won Keun Oh ${ }^{1, * \mathbb{D}}$ \\ 1 Korea Bioactive Natural Material Bank, Research Institute of Pharmaceutical Sciences, College of Pharmacy, \\ Seoul National University, Seoul 08826, Korea; htkquy@ctu.edu.vn (T.K.Q.H.); paul36@snu.ac.kr (B.W.L.); \\ hieusnu@gmail.com (N.H.N.); chgyand@naver.com (H.M.C.); thamtris@snu.ac.kr (T.V.); \\ phuongdoan@snu.ac.kr (T.P.D.) \\ 2 College of Natural Sciences, Cantho University, Campus II, Cantho City 94000, Vietnam \\ 3 Choong Ang Vaccine Laboratory, 1476-37, Yuseong-daero, Yuseong-gu, Daejeon 34055, Korea; \\ ehkim@cavac.co.kr \\ * Correspondence: wkoh1@snu.ac.kr; Tel.: +82-2-880-7872 \\ + These authors contributed equally to this work.
}

Received: 4 April 2020; Accepted: 29 April 2020; Published: 4 May 2020

check for updates

\begin{abstract}
Pinus densiflora was screened in an ongoing project to discover anti-influenza candidates from natural products. An extensive phytochemical investigation provided 26 compounds, including two new megastigmane glycosides (1 and 2), 21 diterpenoids (3-23), and three flavonoids (24-26). The chemical structures were elucidated by a series of chemical reactions, including modified Mosher's analysis and various spectroscopic measurements such as LC/MS and 1D- and 2D-NMR. The anti-influenza A activities of all isolates were screened by cytopathic effect (CPE) inhibition assays and neuraminidase (NA) inhibition assays. Ten candidates were selected, and detailed mechanistic studies were performed by various assays, such as Western blot, immunofluorescence, real-time PCR and flow cytometry. Compound $\mathbf{5}$ exerted its antiviral activity not by direct neutralizing virion surface proteins, such as HA, but by inhibiting the expression of viral mRNA. In contrast, compound 24 showed NA inhibitory activity in a noncompetitive manner with little effect on viral mRNA expression. Interestingly, both compounds $\mathbf{5}$ and $\mathbf{2 4}$ were shown to inhibit nitric oxide (NO) production and inducible nitric oxide synthase (iNOS) expression in a dose-dependent manner. Taken together, these results provide not only the chemical profiling of $P$. densiflora but also anti-influenza A candidates.
\end{abstract}

Keywords: Pinus densiflora; anti-influenza; neuraminidase; H1N1; cytopathic effect; anti-inflammation

\section{Introduction}

According to data from the Centers for Disease Control and Prevention (CDC), it is estimated that $5-10 \%$ of the human population is infected by seasonal human influenza virus each year, and approximately 290,000 to 650,000 people globally die from influenza-related respiratory diseases [1,2]. The influenza virus is divided into four types (A-D) based on the core protein, and the influenza A virus (IAV) is considered the main target for drug development, especially since it is the most devastating in pandemic or epidemic outbreaks [3]. Many efforts have been made to develop anti-influenza A agents that inhibit each key step of IAV from various resources. Major events that occur in viral replication of IAV are as follows: (i) attachment of a virion by interaction between the sialic acid receptor of the host cell and hemagglutinin (HA) on the virion surface; (ii) fusion and 
endocytosis of the virion into the cytoplasm of the host cell; (iii) release of viral ribonucleoprotein (RNP) into the cytoplasm and nuclear import; (iv) transcription and replication of viral RNA; (v) translation and protein synthesis; (vi) assembly of virion composition; and (vii) budding and release of a newly assembled virion by neuraminidase [4].

Pharmaceutical companies have endeavored to develop inhibitors that block any of these aforementioned steps. Among these targets, blocking viral entry and fusion has been emerging as a favorable inhibition target because hemagglutinin, especially, HA2 subunit (stem region of HA) responsible for viral fusion is highly conserved and able to trigger an antibody-mediated immune response during infection [5,6], in which the antibodies induced by HA2 show high cross-reactivity, even toward various different subtypes of influenza virus [7]. As a result, several potent HA inhibitors including cholesterol conjugated short peptide named S-KKWK, chlorogenin 3-O- $\beta$-chacotrioside derivatives, and fucoidan derivatives have been investigated to date [8-10]. For clinically approved drugs, umifenovir interrupts viral fusion by targeting viral HA and is being used as an over-the-counter (OTC) drug in Russia and China [11]. Interestingly, although umifenovir has been used clinically for more than 30 years in Russia, no reports on emergence of resistant viruses from humans have been published so far [12]. DAS181, which prevents binding of the influenza virus by cleaving viral receptors on host epithelical cells, is in phase III clinical trials [13]. Amantadine and rimantadine have been used to inhibit the release of viral RNP as M2 ion channel inhibitors. However, most influenza strains have developed resistance to both drugs [14]. Neuraminidase inhibitors, including zanamivir and oseltamivir, which are most commonly prescribed to treat flu, have been used globally. However, their use has been facing limitations due to the rapid emergence of resistant influenza strains and the risk of side effects [15]. Therefore, the discovery of small molecules that inhibit any step of the virus life cycle and can be used in combination to prevent the rapid occurrence of resistant viruses is still urgent.

Pinus densiflora Siebold and Zucc., commonly known as Korean red pine, is a coniferous evergreen tree with an irregular or umbrella-shaped crown that can grow up to 100 feet tall. P. densiflora belongs to the Pinaceae family and is widely distributed in East Asia, including the Russian Far East, Northern China, Central and Southern Japan, and Korea [16]. Various parts of P. densiflora, such as the needles, resins and pollen, have been listed in two famous ancient pharmacopoeias, Dong-Eu-Bo-Gam (Heo, Joon, AD 1713) [17] of Korea and the Compendium of Materia Medica of China (Li, Shizhen, 1578) [18]. Its resin and pollen as medicinal raw materials can still be found in the Korean Herbal Pharmacopoeia [19]. P. densiflora has been established as having health-promoting properties, including the treatment of strokes and memory improvement as a nourishing tonic [20,21]. In addition, various activities such as the improvement of fatigue, depression, anxiety, cancer, and several chronic diseases have been reported [22,23]. With respect to antiviral properties, potent inhibitory activity of some fractions from $P$. densiflora against HSV (herpes simplex virus) has been suggested experimentally [24]. However, to the best of our knowledge, there have been limited studies evaluating the antiviral properties of $P$. densiflora, especially against influenza $\mathrm{A}$ at the compound level. Regarding its chemical components, essential oils (0.3-1.3\%, antioxidant and antiaging) including $\alpha$-pinene, $\beta$-pinene, camphene, limonene, borneol (6.8\%), bornyl acetate (3.8\%), along with cinnamic acid, benzoic acid, flavonoids, abietane diterpenoid, and stilbenoid (antibacterial and antifungal) have been reported from its leaves [20,25-27]. It has been reported that the pine cones that contain labdane-type diterpenoids that have inhibitory activity against acne [28]. Extensive isolation of the compounds from P. densiflora allowed the purification of 26 compounds with various skeletons, including two previously undescribed megastigmane glycosides (1 and $\mathbf{2}$ ), which contributes to the chemical profiling of constituents in $P$. densiflora. Moreover, all isolated compounds were tested by a cytopathic effect (CPE) assay with H1N1 virus infection, which is an indicator of the potential candidates as being anti-influenza agents. For selected active candidates, various assays including, Western blot, immunofluorescence assay, flow cytometry, and NO production assay, were performed to investigate the anti-influenza mode of action. 


\section{Materials and Methods}

\subsection{General Experimental Procedures}

Optical rotation values were obtained using a JASCO P-2000 polarimeter (JASCO International Co. Ltd., Tokyo, Japan). IR spectra were acquired using a Nicolet 6700 FT-IR spectrometer (Thermo Electron Corp., Waltham, MA, USA). NMR spectra were recorded on an Advance $500 \mathrm{MHz}$ spectrometer (Bruker, Billerica, MA, USA). HRESIMS data were obtained using an Agilent 6530 Q-TOF (Agilent Technologies, Inc., Santa Clara, CA, USA). Column chromatography (CC) was performed with silica gel (63-200 $\mu \mathrm{m}$ particle size, Zeochem, Lake Zurich, Switzerland) and RP-C 18 (75 $\mu \mathrm{m}$ particle size, Nacalai Tesque, Kyoto, Japan). For TLC analysis, RP-18 $\mathrm{F}_{254} \mathrm{~S}$ and silica gel $60 \mathrm{~F}_{254}$ plates, from Merck (Darmstadt, Germany) were used. A Gilson HPLC system equipped with an Optima Pak C18 column $(10 \times 250 \mathrm{~mm}, 10 \mu \mathrm{m}$ particle size; RS Tech, Seoul, Korea) was used for the purification of compounds, with a flow rate of $2 \mathrm{~mL} / \mathrm{min}$ and UV detection at 205 and $254 \mathrm{~nm}$. Industrial-grade solvents (Daejung Chemical, Siheung, Korea) were used for preprocessing, including extraction and fractionation, and analytical-grade solvents (Daejung Chemical) were used for purification of the compounds.

\subsection{Plant Material}

The cortex and leaves of $P$. densiflora were collected from the medicinal plant garden of the College of Pharmacy, Seoul National University, Goyang-si, Gyeonggi-do, Korea $\left(37^{\circ} 71^{\prime} 27^{\prime} \mathrm{N}, 126^{\circ} 81^{\prime} 88^{\prime} \mathrm{E}\right)$. The samples were botanically authenticated by Prof. Won Keun Oh at the College of Pharmacy, Seoul National University. A voucher specimen (SNUPMHG-001837) was deposited at the College of Pharmacy, Seoul National University, Seoul, Republic of Korea.

\subsection{Extraction and Isolation}

The cortex $(1.5 \mathrm{~kg})$ and leaves $(2.5 \mathrm{~kg})$ of $P$. densiflora were extracted separately with $\mathrm{MeOH}$ with the assistance of ultrasonic waves. The combined extracts were then evaporated under reduced pressure to obtain the crude residue. The crude extracts were dispensed in distilled water and successively partitioned with EtOAc and $n$-BuOH. The EtOAc and $n$-BuOH-soluble fractions were then fractionated and purified by repeated normal-phase and reverse-phase chromatography, as well as by preparative HPLC, resulting in the isolation of 26 compounds, including two new megastigmane-type compounds (1 and 2), 21 diterpenoids, and three flavonoids. The isolation scheme and NMR spectra are reported in the Supplementary Material (Figures S1 and S2). All compounds in this study were confirmed to have high purity $(\geq 95 \%)$.

$(2 S, 9 S)-2,9-D i h y d r o x y m e g a s t i g m a n-5-e n e-2-O-\beta$-D-glucopyranoside (1): Colorless gum; $[\alpha]_{\mathrm{D}}^{20}-14.1$ $(c=0.5, \mathrm{MeOH})$; IR $v_{\max } 3360,2969 \mathrm{~cm}^{-1}$; HRESIMS m/z 419.2282 [M+HCOO]- (calcd for $\mathrm{C}_{20} \mathrm{H}_{35} \mathrm{O}_{9}$, 419.2287); ${ }^{1} \mathrm{H}$ and ${ }^{13} \mathrm{C}$ NMR see Table 1.

$(2 R, 9 S)-2,9-D i h y d r o x y m e g a s t i g m a n-5-e n e-2-O-\beta$-D-glucopyranoside $(2)$ : Colorless gum; $[\alpha]_{\mathrm{D}}^{20}-4.7$ $(c=0.5, \mathrm{MeOH}) ; \mathrm{IR} v_{\max } 3358,2969 \mathrm{~cm}^{-1}$; HRESIMS m/z 419.2292 [M+HCOO] $^{-}$(calcd for $\mathrm{C}_{20} \mathrm{H}_{35} \mathrm{O}_{9}$, 419.2287); ${ }^{1} \mathrm{H}$ and ${ }^{13} \mathrm{C}$ NMR see Table 1.

Table 1. NMR Spectroscopic data for compounds 1 and 2.

\begin{tabular}{ccccc}
\hline \multirow{2}{*}{ No. } & \multicolumn{2}{c}{$\mathbf{1}^{a}$} & \multicolumn{2}{c}{$\mathbf{2}^{a}$} \\
\cline { 2 - 5 } & $\delta_{\mathbf{H}}(\boldsymbol{J}$ in Hz) & $\delta_{\mathrm{C}}$ & $\delta_{\mathbf{H}}(\boldsymbol{J}$ in Hz $)$ & $\delta_{\mathrm{C}}$ \\
\hline $\mathbf{1}$ & & 41.5 & & 40.6 \\
$\mathbf{2}$ & $3.43 \mathrm{dd}(3.0,11.0)$ & 87.9 & $3.62 \mathrm{dd}(3.0,10.2)$ & 83.0 \\
$\mathbf{3}$ & $2.04 \mathrm{~m}$ & 27.1 & $1.86 \mathrm{~m}$ & 23.9 \\
& $1.79 \mathrm{~m}$ & \multirow{2}{*}{31.7} & $2.11 \mathrm{td}(4.8,16.8)$ & 31.3 \\
$\mathbf{4}$ & $2.05 \mathrm{~m}$ & & $2.02 \mathrm{~m}$ & \\
& & &
\end{tabular}


Table 1. Cont.

\begin{tabular}{|c|c|c|c|c|}
\hline \multirow{2}{*}{ No. } & \multicolumn{2}{|c|}{$1^{a}$} & \multicolumn{2}{|l|}{$2^{a}$} \\
\hline & $\delta_{\mathrm{H}}(J$ in $\mathrm{Hz})$ & $\delta_{\mathrm{C}}$ & $\delta_{\mathrm{H}}(J$ in $\mathrm{Hz})$ & $\delta_{\mathrm{C}}$ \\
\hline 5 & & 127.3 & & 127.1 \\
\hline 6 & & 137.3 & & 137.5 \\
\hline \multirow[t]{2}{*}{7} & $2.15 \mathrm{dt}(4.5,13.0)$ & 26.0 & $2.21 \mathrm{dt}(4.8,12.0)$ & 26.1 \\
\hline & $2.00 \mathrm{~m}$ & & $1.98 \mathrm{~m}$ & \\
\hline 8 & $1.51 \mathrm{~m}$ & 40.7 & $1.53 \mathrm{~m}$ & 40.8 \\
\hline 9 & $3.72 \mathrm{~m}$ & 69.2 & $3.73 \mathrm{~m}$ & 69.2 \\
\hline 10 & $1.18 \mathrm{~d}(6.0)$ & 23.3 & $1.19 \mathrm{~d}(6.6)$ & 23.3 \\
\hline 11 & $1.15 \mathrm{~s}$ & 22.5 & $1.14 \mathrm{~s}$ & 22.7 \\
\hline 12 & $1.05 \mathrm{~s}$ & 26.4 & $1.04 \mathrm{~s}$ & 26.7 \\
\hline 13 & $1.61 \mathrm{~s}$ & 19.7 & $1.64 \mathrm{~s}$ & 19.7 \\
\hline Glu1 & $4.35 \mathrm{~d}(8.0)$ & 106.6 & $4.36 \mathrm{~d}(7.8)$ & 101.8 \\
\hline Glu2 & $3.22 \mathrm{t}(8.0)$ & 75.7 & 3.22 dd $(7.8,9.0)$ & 75.1 \\
\hline Glu3 & $3.36 \mathrm{~m}$ & 78.3 & $3.39 \mathrm{t}(9.0)$ & 78.3 \\
\hline Glu4 & $3.28 \mathrm{~m}$ & 71.7 & 3.31 t (9.0) & 71.9 \\
\hline Glu5 & $3.26 \mathrm{~m}$ & 77.7 & $3.26 \mathrm{~m}$ & 77.8 \\
\hline \multirow[t]{2}{*}{ Glu6 } & $3.86 \mathrm{dd}(2.0,11.5)$ & 62.8 & $3.88 \mathrm{dd}(1.8,11.4)$ & 63.0 \\
\hline & $3.68 \mathrm{dd}(5.5,11.5)$ & & $3.69 \mathrm{dd}(6.0,11.4)$ & \\
\hline
\end{tabular}

${ }^{a}$ Recorded in methanol- $d_{4}$ at $500 \mathrm{MHz}$.

\subsection{Enzymatic Hydrolysis of 2}

A solution of $2(4.4 \mathrm{mg})$ in $20 \mathrm{mM}$ acetate buffer (approximately pH 5.0, $0.5 \mathrm{~mL}$ ) was treated

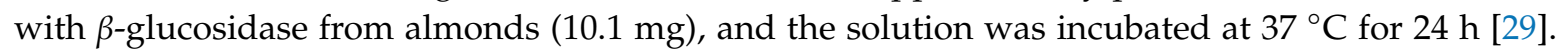
The mixture was further incubated after the addition of $\beta$-glucosidase $(5.3 \mathrm{mg})$ for $28 \mathrm{~h}$. The reaction mixture was dried under a $\mathrm{N}_{2}$ stream after cooling and subjected to silica gel column chromatography (16.5 g, $\Phi=15 \mathrm{~mm}, L=25 \mathrm{~cm}$ ). The residue was eluted from $n$-hexane and acetone (3/1) to methanol. The aglycone $2 \mathbf{a}(1.2 \mathrm{mg})$ was obtained in fractions 18-20. Aglycone (2a): Colorless syrup, $[\alpha]_{\mathrm{D}}^{20}+15.3$ $\left(c=0.2, \mathrm{CHCl}_{3}\right) ;{ }^{1} \mathrm{H}-\mathrm{NMR}\left(\mathrm{CH}_{3} \mathrm{OD}, 400 \mathrm{MHz}\right) \delta: 3.41(\mathrm{dd}, J=10.0,3.6 \mathrm{~Hz}, \mathrm{H}-2), 1.71(\mathrm{~m}, \mathrm{H}-3), 2.03$ (overlapped, H-4), 2.20 (m, H-7a), 1.95 (m, H-7b), 1.50 (m, H-8), 3.71 (m, H-9), 1.17 (d, J = 6.4 Hz, H-10), 0.96 (s, H-11), 1.07 (s, H-12), 1.61 (s, H-13); ${ }^{13} \mathrm{C}-\mathrm{NMR}\left(\mathrm{CH}_{3} \mathrm{OD}, 100 \mathrm{MHz}\right)$ 8: 41.3 (C-1), 76.9 (C-2), 27.9 (C-3), 31.5 (C-4), 127.1 (C-5), 137.3 (C-6), 26.1 (C-7), 40.7 (C-8), 69.2 (C-9), 23.3 (C-10), 21.8 (C-11), 26.4 (C-12), 19.8 (C-13); HRESIMS (positive-ion mode): $m / z: 213.1853[\mathrm{M}+\mathrm{H}]^{+}\left(\right.$calcd $\left.\mathrm{C}_{13} \mathrm{H}_{25} \mathrm{O}_{2}: 213.1849\right)$ (Figures S13-S16).

\subsection{Preparation of 2,9-Di-(S)-MTPA Ester (2b) and 2,9-Di-(R)-MTPA Ester (2c) from 2a}

The absolute configuration of C-9 in 2 was determined by modified Mosher's analysis [30]. After transferring $2 \mathbf{a}(0.4 \mathrm{mg}, 1.9 \mu \mathrm{mol})$ in dry pyridine $(4.8 \mu \mathrm{L}, 60 \mu \mathrm{mol}), 0.5 \mathrm{~mL}$ of anhydrous $\mathrm{CH}_{2} \mathrm{Cl}_{2}$ was added to the mixture for dissolution. Then, $R$-(-)-MTPA-Cl $(15 \mu \mathrm{L}, 78.3 \mu \mathrm{mol})$ was added to the mixture, and the reaction was initiated at ambient temperature for $6 \mathrm{~h}$. The progress of the reaction was monitored by TLC using $n$-hexane and acetone (3:1). After the reaction was complete, the resulting solution was dried under a $\mathrm{N}_{2}$ stream and dissolved in distilled water, followed by repeated partitioning with $\mathrm{CH}_{3} \mathrm{Cl}$. The combined $\mathrm{CH}_{3} \mathrm{Cl}$ extracts containing 2,9-di-(S)-MTPA ester (2b) were dried, and ${ }^{1} \mathrm{H}-\mathrm{NMR}$ and ${ }^{1} \mathrm{H}^{-1} \mathrm{H}$ COSY were recorded in $\mathrm{CDCl}_{3}$. 2,9-Di-(R)-MTPA ester (2c) was also prepared in a similar manner as $\mathbf{2 b}$. Compound $\mathbf{2 b}$ : ${ }^{1} \mathrm{H}-\mathrm{NMR}\left(600 \mathrm{MHz}, \mathrm{CDCl}_{3}\right) \delta: 4.95$ (dd, $J=9.6,3.0 \mathrm{~Hz}, \mathrm{H}-2), 1.83-1.91$ (m, H-3), 1.99-2.06 (overlapped, H-4), 2.05 (overlapped, H-7a), 1.93 (overlapped, H-7b), 1.66 (m, H-8a), 1.60 (m, H-8b), 5.10 (m, H-9), 1.28 (d, J = 6.0, H-10), 0.89 (s, H-11), 0.91 (s, H-12), 1.54 (s, H-13); HR-ESI-MS (positive-ion mode): $m / z: 662.2899\left[\mathrm{M}+\mathrm{NH}_{4}\right]^{+}$ (calcd $\mathrm{C}_{33} \mathrm{H}_{42} \mathrm{~F}_{6} \mathrm{NO}_{6}$ : 662.2911) (Figure S17). Compound 2c: ${ }^{1} \mathrm{H}-\mathrm{NMR}\left(600 \mathrm{MHz}, \mathrm{CDCl}_{3}\right) \delta: 4.89$ (dd, $J=9.0,3.0 \mathrm{~Hz}, \mathrm{H}-2), 1.77-1.85$ (m, H-3), 1.92-1.98 (overlapped, H-4), 1.92 (overlapped, H-7a), 
1.88 (overlapped, H-7b), 1.61 (m, H-8a), 1.56 (m, H-8b), 5.13 (m, H-9), 1.35 (d, J = 6.6, H-10), 0.87 (s, H-11), 0.92 (s, H-12), 1.46 (s, H-13); HR-ESI-MS (positive-ion mode): $m / z: 662.2911\left[\mathrm{M}+\mathrm{NH}_{4}\right]^{+}$ (calcd $\mathrm{C}_{33} \mathrm{H}_{42} \mathrm{~F}_{6} \mathrm{NO}_{6}$ : 662.2911) (Figure $\mathrm{S} 18$ ).

\subsection{Sugar Analysis of Compounds $\mathbf{1}$ and $\mathbf{2}$}

The absolute configuration of the sugars was determined by means of HPLC analysis after derivatization, which was proposed by Tanaka [31]. A solution of $\mathbf{1}(0.6 \mathrm{mg})$ in $2 \mathrm{M}$ hydrochloric acid was incubated at $100{ }^{\circ} \mathrm{C}$ for $4.5 \mathrm{~h}$. The hydrolysates were neutralized with $\mathrm{Na}_{2} \mathrm{CO}_{3}$ and concentrated under a $\mathrm{N}_{2}$ stream. L-Cysteine methyl ester $(0.6 \mathrm{mg})$ in pyridine was added to the dried residue and subjected to incubation at $60{ }^{\circ} \mathrm{C}$ for $1 \mathrm{~h}$. Then, $0.6 \mathrm{mg}$ of phenyl isothiocyanate was added to the resulting mixture and incubated under the same conditions for $1 \mathrm{~h}$. After cooling and filtration, $10 \mu \mathrm{L}$ of the solution was directly analyzed by reverse-phase HPLC [HPLC: Thermo Fisher Ultimate 3000 system (Germering, Germany); YMC Triart C18 column $(4.6 \times 250 \mathrm{~mm}, 5 \mu \mathrm{m}$ particle size; YMC Co., Kyoto, Japan); conditions were as follows: $\mathrm{MeCN}: \mathrm{H}_{2} \mathrm{O}=25: 75$ (v:v); a diode array detector at $250 \mathrm{~nm}$; and a flow rate of $0.8 \mathrm{~mL} / \mathrm{min}$. The UV pattern and retention time of the derivatized sugar in compound 1 were compared to those of derivatized authentic D,L-glucose. The absolute configuration of the sugar in compound $\mathbf{2}$ was determined in a similar manner. The retention time of derivatives of D-glucose is $19.753 \mathrm{~min}$, whereas that of L-glucose is $17.663 \mathrm{~min}$. As derivatives of compounds $\mathbf{1}$ and $\mathbf{2}$ were eluted at $19.767 \mathrm{~min}$ and $19.800 \mathrm{~min}$, respectively, the sugar moieties of both $\mathbf{1}$ and $\mathbf{2}$ were proven to be in the D-configuration.

\subsection{Cell Culture and Virus Stock}

Madin-Darby Canine Kidney (MDCK) cells and RAW264.7 cells were provided by American Type Culture Collection (ATCC, Manassas, VA 20108, USA). The cells were maintained in Dulbecco's modified Eagle's medium (DMEM) (HyClone, Logan, UT) supplemented with 10\% fetal bovine serum (FBS) (HyClone, Logan, UT), $100 \mathrm{U} / \mathrm{mL}$ penicillin and $100 \mu \mathrm{g} / \mathrm{mL}$ streptomycin (GIBCO-BRL, Grand Island, NY, USA). Influenza viruses (H1N1 A/PR/8/34 virus, H9N2 A/chicken/Korea/01210/2001 virus) were obtained from Choong Ang Vaccine Laboratory, Korea and stored at $-80^{\circ} \mathrm{C}$.

\subsection{Cytopathic Effect (CPE) Inhibition Assay}

Cytopathic effect and cytotoxicity assays were performed as previously described [32]. Briefly, MDCK cells were grown in 96-well plates for $24 \mathrm{~h}$. The cells were inoculated with influenza viruses (H1N1 A/PR/8/34 virus or H9N2 A/chicken/Korea/01210/2001 virus) at 0.01 MOI using DMEM containing $0.15 \mu \mathrm{g} / \mathrm{mL}$ trypsin and $5 \mu \mathrm{g} / \mathrm{mL}$ bovine serum albumin (BSA) (Sigma, St Louis, MO, USA). After $2 \mathrm{~h}$ of incubation, the cells were washed with phosphate-buffered saline (PBS) (TaKaRa, Japan) and the medium was replaced with new medium containing the test compounds. The cells were continually incubated for 3 days at $37^{\circ} \mathrm{C}$ under a $5 \% \mathrm{CO}_{2}$ atmosphere. Then, the medium was replaced with fresh DMEM, and $20 \mu \mathrm{L}$ of $2 \mathrm{mg} / \mathrm{mL}$ 3-(4,5-dimethyl-2-thiazolyl)-2,5-diphenyl-2H-tetrazolium bromide (MTT) solution (Sigma, St Louis, MO, USA) was added to each well. After $4 \mathrm{~h}$ of incubation, the supernatant was removed and formazan crystals were dissolved in $100 \mu \mathrm{L}$ of DMSO. The absorbance was measured at a wavelength of $550 \mathrm{~nm}$. Similarly, the cytotoxicity assay was carried out using 96-well plates. After $24 \mathrm{~h}$ of incubation, MDCK cells were washed with PBS and treated with the test compounds. The culture was treated with $20 \mu \mathrm{L}$ of $2 \mathrm{mg} / \mathrm{mL}$ MTT solution in each well after 2 days of incubation. The final steps followed those described above.

\subsection{Quantitative Real-Time PCR}

MDCK cells were maintained in 6-well plates and infected with the H1N1 A/PR/8/34 virus for $2 \mathrm{~h}$. The cells were washed twice with PBS and the medium was replaced with new media containing the test compounds. The TRIzol method was used to isolate total RNA from the cells after $24 \mathrm{~h}$ of incubation [33]. Total RNA was reverse transcribed using random primers (Invitrogen, USA) according 
to the manufacturer's instructions. Real-time PCR was performed using selective primers for H1N1 (Table S5) (Enotech, Korea) using the Maxima SYBR Green qPCR master mix 2X kit (Thermo Sci., Rockford, IL, USA). The StepOnePlus ${ }^{\mathrm{TM}}$ real-time PCR system was used with cycling conditions as follows: $95^{\circ} \mathrm{C}$ for $10 \mathrm{~min}$, followed by 40 cycles of $95^{\circ} \mathrm{C}$ for $15 \mathrm{sec}$ and $60^{\circ} \mathrm{C}$ for $1 \mathrm{~min}$. The data were calculated using StepOne software v2.3 (Applied Biosystems).

\subsection{Western Blotting Analysis}

The cultures were prepared similarly to the cultures prepared for the quantitative real-time PCR assay. However, after $24 \mathrm{~h}$ of incubation, the cells were washed with cold PBS and stored at $-80^{\circ} \mathrm{C}$ until use. The cells were then lysed with lysis buffer [50 mM Tris- $\mathrm{HCl}$ (pH 7.6), $120 \mathrm{mM} \mathrm{NaCl}, 1 \mathrm{mM}$ EDTA, $0.5 \% \mathrm{NP}-40$, and $50 \mathrm{mM} \mathrm{NaF}$. The protein concentrations of the lysates were determined using a protein assay kit (Bio-Rad Laboratories Inc., USA) and electrophoresed on 12\% SDS-polyacrylamide gels [34]. The gels were electrotransferred to polyvinylidene fluoride membranes (PVDF 0.45 $\mu \mathrm{m}$, Immobilon-P, USA). The membranes were blocked with a 5\% skim milk solution (Becton Dickinson, USA) and then incubated with primary antibodies: neuraminidase (NA; Gene Tex, San Antonio, TX, USA), hemagglutinin (HA; Sigma, St Louis, MO, USA) or mouse monoclonal actin (Abcam, Cambridge, UK). After overnight incubation, the membranes were further incubated with secondary antibodies (Goat anti-Rabbit IgG (H + L) HRP or Goat anti-Mouse IgG (H + L) HRP; Thermo Sci., Rockford, IL, USA) for $2 \mathrm{~h}$ and detected by a chemiluminescence Western blotting detection kit (Thermo Sci., Rockford, IL, USA) using Image Reader LAS-4000 software.

\subsection{Immunofluorescence Assay}

MDCK cells were grown on sterilized glass coverslips for $24 \mathrm{~h}$. Then, the cells were infected with the H1N1 A/PR/8/34 virus for $2 \mathrm{~h}$, washed twice with PBS and the medium was replaced with new media containing the test compounds. The cultures were continually incubated at $37^{\circ} \mathrm{C}$ under a $5 \% \mathrm{CO}_{2}$ atmosphere for $24 \mathrm{~h}$. After washing with PBS (pH 7.4), the cells were fixed with a $4 \%$ paraformaldehyde solution for $30 \mathrm{~min}$ at room temperature and blocked with a 1\% BSA solution for $1 \mathrm{~h}$. The cells were incubated overnight with a rabbit monoclonal antibody against NA (GeneTex, San Antonio, TX, USA) diluted 1:50 in PBS (pH 7.4). After being washed with PBS, the cells were incubated with a secondary FITC-conjugated Goat anti-Rabbit IgG antibody (Abcam, Cambridge, UK). After washing with PBS (pH 7.4) [34], the cells were stained with 500 nM DAPI solution for $10 \mathrm{~min}$ at room temperature and washed again with PBS (pH 8.0). Slides were mounted and imaged by fluorescence microscopy (Olympus ix70 Fluorescence Microscope, USA).

\subsection{Flow Cytometric Analysis of the Cell Cycle}

MDCK cells were maintained in 36-mm culture dishes and infected with the H1N1 A/PR/8/34 virus for $2 \mathrm{~h}$. After washing with PBS and replacing the media with new media containing the test compounds, the cultures were incubated for 3 days at $37{ }^{\circ} \mathrm{C}$ under a $5 \% \mathrm{CO}_{2}$ atmosphere. The cell suspensions were collected from adherent cells and detached cells. After that, the cells were washed with cold PBS and fixed with precooled $70 \%$ ethanol solution. After overnight incubation at $4{ }^{\circ} \mathrm{C}$, the cells were stained with $20 \mu \mathrm{g} / \mathrm{mL}$ PI (propidium iodide) in PBS solution for $30 \mathrm{~min}$ at room temperature [35]. The cellular DNA contents were analyzed using a flow cytometer (BD, FACSCalibur, San Jose, CA, USA). Data were collected for at least 10,000 cells per sample. In each phase of the viral-infected cell cycle, the distribution of cells is displayed using histograms.

\subsection{Neuraminidase Inhibition and Kinetic Assays}

NA inhibition and kinetic assays were performed as previously described [32,36]. In general, NA activity was measured using 2'-(4-methylumbelliferyl)- $\alpha$-D-N-acetylneuraminic acid (4-MU-NANA) (Sigma-Aldrich Co., USA) as the fluorescent substrate in 96-well plates. Briefly, $10 \mu \mathrm{L}$ of test compounds diluted in enzyme buffer (32.5 mM 2-(N-morpholino) ethanesulfonic acid, $4 \mathrm{mM} \mathrm{CaCl} 2, \mathrm{pH}$ 6.5) 
and $10 \mu \mathrm{L}$ of virus suspension containing NAs from four subtypes (H1N1 A/PR/8/34 virus, H9N2 $\mathrm{A} /$ chicken/Korea/01210/2001 virus, wild-type (wt) pandemic 2009 H1N1 virus (A/California/07/2009), oseltamivir-resistant virus (H274Y mutation) were coincubated for $30 \mathrm{~min}$ at $37^{\circ} \mathrm{C}$. Then, $30 \mu \mathrm{L}$ of $42 \mu \mathrm{M} 4$-MU-NANA substrate in enzyme buffer was added to each well. The enzymatic reactions were maintained at $37^{\circ} \mathrm{C}$ for $2 \mathrm{~h}$ and quenched with $150 \mu \mathrm{L}$ of stop solution $(25 \% \mathrm{EtOH}, 0.1 \mathrm{M}$ glycine, $\mathrm{pH}$ 10.7). The fluorescence was measured with an excitation wavelength of $360 \mathrm{~nm}$ and an emission wavelength of $440 \mathrm{~nm}$ using a SpectraMax GEMINI XPS microplate reader (Molecular Devices, Sunnyvale, CA, USA). The enzymatic kinetic assay was performed in a similar manner as that of the NA inhibition assay. The product 4-methylumbelliferone was measured immediately without adding stop solution. The inhibition type was analyzed using SigmaPlot 11.0 (SPCC Inc., Chicago, IL, USA).

\subsection{Cell Protection Assay for H1N1 Infection via Coincubation}

In order to evaluate the effect of coincubation of compounds 5 and 24 with the host cells, MDCK cells were preincubated with the two test compounds $(20 \mu \mathrm{M})$ for $4 \mathrm{~h}$ at $37^{\circ} \mathrm{C}$, followed by H1N1 $\mathrm{A} / \mathrm{PR} / 8 / 34$ virus infection [37]. After $1 \mathrm{~h}$ incubation at $37^{\circ} \mathrm{C}$ under a $5 \% \mathrm{CO}_{2}$ atmosphere, the cells were washed twice with PBS. Then, the medium was replaced with fresh medium and the cells were incubated for 3 days. The antiviral activity was evaluated by a cytotoxicity assay.

\subsection{Virus Particles Assay for H1N1 Infection via Coincubation}

In order to evaluate the effect of coincubation of compounds $\mathbf{5}$ and $\mathbf{2 4}$ with virus regarding its infectivity, H1N1 A/PR/8/34 virus diluted with DMEM containing $0.15 \mu \mathrm{g} / \mathrm{mL}$ trypsin and $5 \mu \mathrm{g} / \mathrm{mL}$ BSA was incubated with or without the test compounds $(20 \mu \mathrm{M})$ for $1 \mathrm{~h}$ at $4{ }^{\circ} \mathrm{C}$ [37]. Then, MDCK cells were incubated with the viral medium for $1 \mathrm{~h}$ at $37^{\circ} \mathrm{C}$ under a $5 \% \mathrm{CO}_{2}$ atmosphere. The monolayers of cells were washed twice with PBS and incubated for 3 days in new medium. The antiviral activity was evaluated by a cytotoxicity assay.

\subsection{Nitric Oxide (NO) Production Assay}

DMEM without phenol red (WelGene, Korea) was used for the NO production assay. Briefly, RAW 264.7 cells were seeded into 12-well plates and incubated for 1 day at $37^{\circ} \mathrm{C}$ under a $5 \% \mathrm{CO}_{2}$ atmosphere. The cells were treated with the test compounds for $10 \mathrm{~h}$ before infection with the H1N1 $\mathrm{A} / \mathrm{PR} / 8 / 34$ virus at high MOI (1.0) and low MOI (0.01) for $1 \mathrm{~h}$ [38]. The medium was replaced with new medium and the cells were further incubated for $12 \mathrm{~h}$. Nitric oxide production was evaluated by using the Griess reagent method, and the absorbance was measured at $540 \mathrm{~nm}$ [39]. For the NO assay stimulated by lipopolysaccharide (LPS), RAW 264.7 cells were pretreated with the test compounds for $10 \mathrm{~h}$, and $100 \mathrm{ng} / \mathrm{mL}$ LPS was added to the cells. After $12 \mathrm{~h}$ of incubation, NO production was measured as described above. Inducible nitric oxide synthase (iNOS) expression was measured by Western blot. Briefly, RAW 264.7 cells were maintained in 6-well plates for $24 \mathrm{~h}$. The cells were preincubated with test compounds for $10 \mathrm{~h}$, and then $100 \mathrm{ng} / \mathrm{mL}$ LPS was added to the culture. The cells were collected after $12 \mathrm{~h}$ of incubation. The Western blot method was performed as described above with a monoclonal iNOS antibody (Thermo Sci., Rockford, IL, USA).

\subsection{Simulation of Binding Affinity via Molecular Docking}

In order to evaluate the binding affinity between the ligands and influenza viral polymerase or NA in silico, the docking study using Discovery Studio 4.0/CDOCKER (Accelrys, San Diego, CA) was performed [40]. The crystal structure of the influenza A virus nucleoprotein (NP; PDB ID: 3RO5), the PA-PB1 complex from influenza virus RNA polymerase (PDB ID: 2ZNL), the 2009 pandemic H1N1 NA complex (PDB ID: 3TI4), and the N1 NA H274Y (PDB ID: 3CL0) were supplied from the Protein Data Bank (http://www.pdb.org) [41-44]. Ligand interaction affinity was calculated by CDOCKER interaction energy and interacting bonds such as van der Waals, salt bridge, attractive 
charge, conventional hydrogen bond, carbon hydrogen bond, pi-cation, pi-anion, pi-alkyl, and pi-pi T-shaped bonds.

\subsection{Statistical Analysis}

The results were obtained from three independent experiments. Statistical calculations were conducted with Sigma Plot Statistical 11.0, SPSS Statistics 23, StepOne software v2.3, and a LAS 4000 luminescent image analyzer. The results were calculated as the means \pm SD of two to three independent experiments $\left({ }^{*} p<0.05,{ }^{* *} p<0.01\right.$, and ${ }^{* *} p<0.001$ using one-way ANOVA statistics).

\section{Results and Discussion}

\subsection{Isolation and Structural Elucidation of Compounds Isolated from P. densiflora}

The cortex and leaves of $P$. densiflora were extracted with MeOH. Following ioassay-guided fractionation, the EtOAc and $n$ - $\mathrm{BuOH}$ soluble fractions were then fractionated and purified by column chromatography and preparative HPLC, resulting in the isolation of 26 compounds, including two new megastigmane-type compounds (1 and 2), 21 diterpenoids (3-23), and three flavonoids (24-26).

Compound 1 was isolated as colorless gum with the molecular formula $\mathrm{C}_{19} \mathrm{H}_{34} \mathrm{O}_{7}$, which was established from the negatively charged ion $\left[\mathrm{M}+\mathrm{HCOO}^{-}\right.$at $\mathrm{m} / z 419.2282$ (calcd. for $\mathrm{C}_{20} \mathrm{H}_{35} \mathrm{O}_{9}$, 419.2287) in the HRESIMS spectrum (Figure S3), corresponding to three double-bond equivalents. The ${ }^{1} \mathrm{H}$ NMR data showed the presence of three singlet methyl groups $\left[\left(\delta_{\mathrm{H}} 1.15(\mathrm{~s}, \mathrm{H}-11), \delta_{\mathrm{H}} 1.05\right.\right.$ $(\mathrm{s}, \mathrm{H}-12)$ and $\left.\delta_{\mathrm{H}} 1.61(\mathrm{~s}, \mathrm{H}-13)\right]$, one doublet methyl group at $\delta_{\mathrm{H}} 1.18(\mathrm{~d}, J=6.0 \mathrm{~Hz}, \mathrm{H}-10)$, two oxygenated methine protons $\left[\delta_{\mathrm{H}} 1.61(\mathrm{dd}, J=3.0,11.0 \mathrm{~Hz}, \mathrm{H}-2)\right.$ and $\left.\delta_{\mathrm{H}} 3.72(\mathrm{~m}, \mathrm{H}-9)\right]$, and sugar ring protons at $\delta_{\mathrm{H}} 3.22-3.86\left(\mathrm{H}-2^{\prime}-\mathrm{H}-5^{\prime}\right)$ along with one anomeric doublet signal at $\delta_{\mathrm{H}} 4.35(\mathrm{~d}, J=8.0 \mathrm{~Hz})$ (Figure S4). The ${ }^{13} \mathrm{C}$ NMR spectrum showed 13 resonances except for the sugar moiety, including two $\mathrm{sp}^{2}$ carbons at $\delta_{\mathrm{C}} 127.3$ and 137.3, two oxygenated $\mathrm{sp}^{3}$ carbons at $\delta_{\mathrm{C}} 87.9$ and 69.2 , and nine $\mathrm{sp}^{3}$ carbons in the $\delta_{\mathrm{C}} 20-50 \mathrm{ppm}$ range (Figure S5). The characteristic deshielded chemical shifts at $\delta_{\mathrm{H}} 3.72(\mathrm{~m}) / \delta_{\mathrm{C}} 69.2$ of $\mathrm{H}-9 / \mathrm{C}-9$, the number of carbons of the core structure, and the existence of a long chain $\left(\mathrm{H}_{7}-\mathrm{H}_{8}-\mathrm{H}_{9}-\mathrm{H}_{10}\right)$ and a fragment $\mathrm{H}_{2}-\mathrm{H}_{3}-\mathrm{H}_{4}$ in the structure supported by the ${ }^{1} \mathrm{H}-{ }^{1} \mathrm{H}$ COSY correlations demonstrated that compound $\mathbf{1}$ is an ionone derivative of the megastigmane class (Figure $\mathrm{S7}$ ). As oxygenated $\mathrm{C}_{13}$-norisoprenoids, megastigmanes are classified into two series, the damascene series (C-7) and the ionone series (C-9), according to the position of oxygenation. The linkage of the sugar molecule with the aglycone was determined by the HMBC correlation from $\mathrm{H}-1^{\prime}\left(\delta_{\mathrm{H}} 4.35\right)$ to $\mathrm{C}-2\left(\delta_{\mathrm{C}} 87.9\right)$ (Figure $\mathrm{S6}$ ). The planar structure of $\mathbf{1}$ was also supported by comparison of NMR data with those of the previously reported platanionoside J after hydrolysis, except for the difference in chemical shift of C-2 $\left(\delta_{C} 87.9\right.$ vs. 77.0$)$ where glycosylation occurred in 1 [45].

Compound $\mathbf{2}$ was also isolated in the same fraction as $\mathbf{1}$ by preparative HPLC. Its molecular formula was determined to be $\mathrm{C}_{19} \mathrm{H}_{34} \mathrm{O}_{7}$ by a negative peak [M $+\mathrm{HCOO}^{-}$at $\mathrm{m} / \mathrm{z} 419.2294$ (calcd for $\mathrm{C}_{20} \mathrm{H}_{35} \mathrm{O}_{9}$, 419.2287) in the HRESIMS spectrum (Figure S8). Interestingly, the ${ }^{1} \mathrm{H}$ and ${ }^{13} \mathrm{C}$ NMR data of $\mathbf{2}$ were found to be similar to those of $\mathbf{1}$ (Table 1), indicating that those two compounds might share the same skeleton but differentiate from each other in absolute configuration. Compound 2 was also determined to be of megastigmane type by four methyl signals at $\delta_{\mathrm{H}} 1.14$ (s, H-11), 1.04 $(\mathrm{s}, \mathrm{H}-12), 1.64(\mathrm{~s}, \mathrm{H}-13)$ and $1.19(\mathrm{~d}, J=6.6 \mathrm{~Hz}, \mathrm{H}-10)$ and 13 carbons constituting the aglycone and sugar moiety, which was observed by an anomeric proton signal resonating at $\delta_{\mathrm{H}} 4.36(\mathrm{~d}, J=7.8 \mathrm{~Hz})$ and an anomeric carbon at $\delta_{\mathrm{C}} 101.8$ (Figures S9-S12). By spectral comparison with $\mathbf{1}$, the difference in the absolute configuration of compound 2 lies at the $\mathrm{C}-2$ position. The spectral differences originating from C-2 between 1 and 2 were observed in the C-1, 2, 3, and C-1' positions. Compound 1 exhibited its carbon resonances of $C-1,2,3$ and $1^{\prime}$ at $\delta_{C} 41.5,87.9,27.1$ and 106.6, respectively, whereas compound 2 showed its corresponding resonances at $\delta_{C} 40.6,83.0,23.9$, and 101.8, which indicated the possibility of opposite stereochemistry of the C-2 position (Table 1). As the sugar moieties of $\mathbf{1}$ and $\mathbf{2}$ were determined to be $\beta$-D-glucose by ${ }^{3} J_{1^{\prime}, 2^{\prime}}$, which is distinct from that of $\alpha$-D-glucose (Table 1) [46] and 
the derivatizing method for HPLC analysis (Figure S21) [31], the absolute configuration of C-2 in 1 and 2 could be determined by the application of $\beta$-D-glucopyranosylation-induced chemical shifts [47]. This can be applied to $\beta$-D-glucosides of secondary alcohols, especially isoprenoid- $\beta$-D-glucopyranosides and $\beta$-D-mannopyranoside, having at least one equatorial alkyl substituent on one of its $\beta$-carbons. The C-1' (the first carbon of the sugar moiety) resonance of glucosides of $S$-alcohols is deshielded, appearing at $\delta_{\mathrm{C}} 106.4 \pm 0.5 \mathrm{ppm}$, whereas this carbon resonance in an $R$-alcohol appears in a relatively upfield region, $\delta_{C} 101.6 \pm 0.9 \mathrm{ppm}$. Moreover, the signal of the chiral $\alpha$-carbon where hydroxylation occurs in alcohols is generally displaced by $+7.0 \pm 0.6 \mathrm{ppm}$ upon glycosylation, whereas a more remarkable deshielding of the $\alpha$-carbon signal is observed (by approximately $+10-11 \mathrm{ppm}$ ) in the case of $\beta$-D-glucosides of secondary $S$-alcohols containing at least one equatorial alkyl substituent on one of its $\beta$-positions. Since the carbon resonances of C-1' in compounds 1 and 2 appeared at $\delta_{C}$ 106.6 and $101.8 \mathrm{ppm}$, respectively, and the chemical shift difference of the $\mathrm{C}-2, \beta$-carbons, between 2 $\left(\delta_{\mathrm{C}} 83.0\right)$ and the aglycone of $\mathbf{2}\left(\delta_{\mathrm{C}} 76.9\right)$, the absolute configurations of C-2 in $\mathbf{1}$ and $\mathbf{2}$ were readily determined to be $S$ and $R$, respectively. Compounds 1 and $\mathbf{2}$ possess the opposite configuration at C-2 and their NMR spectra were not identical, suggesting that they are in a diastereomeric relationship, and they will have the same stereochemistry at C-9. Therefore, elucidating the absolute configuration of C-9 of either compound will enable the confirmation of C-9 of the other compound. As compound $\mathbf{2}$ was isolated with a relatively higher yield compared to 1, compound $\mathbf{2}$ was subjected to enzymatic hydrolysis and modified Mosher's analysis [29,30]. As a result (Figure 1, Figures S19 and S20), the stereochemistry at C-9 was determined to be $9 S$ and that of C-2 was also confirmed to be $2 R$, initially derived from glycosylation-induced chemical shifts. Hence, compounds $\mathbf{1}$ and 2 were determined as $(2 S, 9 S)$-2,9-dihydroxymegastigman-5-ene-2-O- $\beta$-D-glucopyranoside (1) and (2R,9S)-2,9-dihydroxymegastigman-5-ene-2-O- $\beta$-D-glucopyranoside (2).

A

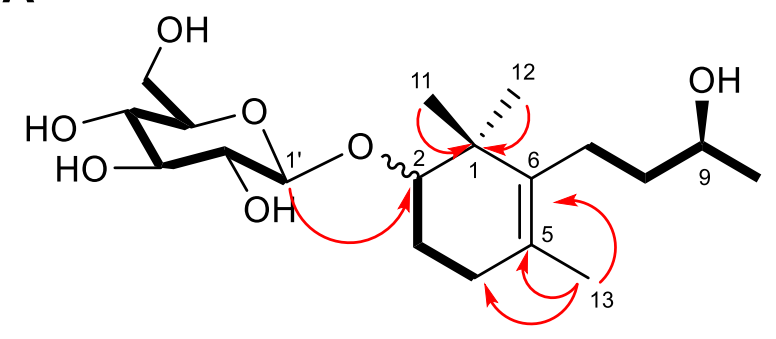

B

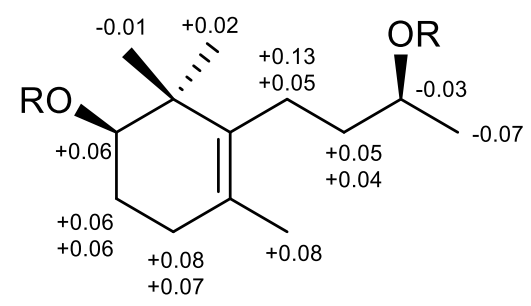

2a: $\mathrm{R}=\mathrm{H}$

2b: $\mathrm{R}=(S)-\mathrm{MTPA}$

2c: $\mathrm{R}=(R)-\mathrm{MTPA}$

Figure 1. (A) Key HMBC (arrows) and COSY (bold) correlations of compounds 1 and 2. (B) Data from the modified Mosher's method for $2 \mathbf{a}$.

The structures of all known compounds isolated from the cortex and leaves of P. densiflora were elucidated by extensive analyses of spectroscopic data including NMR and MS spectra and by comparison with previously reported data as follows: (3) dehydroabietic acid [48]; (4) 12-hydroxydehydroabietic acid [49]; (5) $7 \alpha$-methoxydehydroabietic acid [50]; (6) 15-hydroxydehydroabietic acid [51]; (7) 16-nor-15-oxodehydroabietic acid [52,53]; (8) abieta-8,11,13,15-tetraen-18-oic acid [53]; (9) $7 \alpha$-hydroxyabieta-8,11,13,15-tetraen-18-oic acid [54]; (10) karamatsuic acid [55]; (11) palustric acid [56]; (12) 12-methoxy-7,13-abietadien-18-oic acid [57]; (13) 7-oxo-13 $\beta$-hydroxyabiet-8(14)-en-18-oic acid [58]; (14) 9,13 $\beta$-epidioxy-8(14)-abieten-18-oic acid [59]; (15) 14 $\alpha$,15-epoxyabiet-9(11)-en-12-oxo-18-oic acid [60]; (16) 8(14)-podocarpen-13-on-18-oic acid [51,52]; (17) 8(14)-podocarpen-7,13-dion-18-oic acid [51,52]; (18) 4-epi-trans-communol [61]; (19) 4-epi-trans-communal [62]; (20) 4-epi-trans-communic acid [63]; (21) 3ß-hydroxy-12,13(E)-biformen [64]; 
(22) $18 \alpha, 3 \alpha$-dihydroxy-12,13(E)-biformen [65]; (23) (13S)-15-hydroxylabd-8(17)-en-18-oic acid [66]; (24) ampelopsin [67]; (25) 5,7,4'-trihydroxy-3-methoxy-6-C-methylflavone [68]; and (26) 5,4'-dihydroxy-3,6,7-trimethoxy-8-C-methylflavone [69] (see Supplementary Material) (Figure 2).

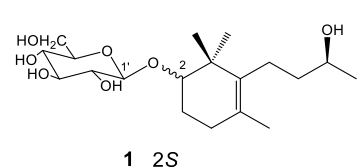
$\begin{array}{ll}1 & 2 S \\ 2 & 2 R\end{array}$

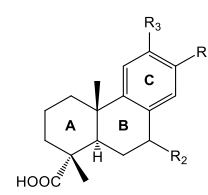

$3 \mathrm{R}_{1}=\mathrm{CH}\left(\mathrm{CH}_{3}\right)_{2}, \mathrm{R}_{2}=\mathrm{H}, \mathrm{R}_{3}=\mathrm{H}$ $4 \mathrm{R}_{1}=\mathrm{CH}\left(\mathrm{CH}_{3}\right)_{2}, \mathrm{R}_{2}=\mathrm{H}, \mathrm{R}_{3}=\mathrm{OH}$ $5 \mathrm{R}_{1}=\mathrm{CH}\left(\mathrm{CH}_{3}\right)_{2}, \mathrm{R}_{2}=\mathrm{OCH}_{3}, \mathrm{R}_{3}=\mathrm{H}$ $6 \mathrm{R}_{1}=\mathrm{C}(\mathrm{OH})\left(\mathrm{CH}_{3}\right)_{2}, \mathrm{R}_{2}=\mathrm{H}, \mathrm{R}_{3}=\mathrm{H}$ $6 \mathrm{R}_{1}=\mathrm{C}(\mathrm{OH})\left(\mathrm{CH}_{3}\right), \mathrm{R}_{2}=\mathrm{H}, \mathrm{R}$
$7 \mathrm{R}_{1}=\mathrm{COCH}_{3}, \mathrm{R}_{2}=\mathrm{H}, \mathrm{R}_{3}=\mathrm{H}$ $8 \mathrm{R}_{1}=\mathrm{C}\left(=\mathrm{CH}_{2}\right) \mathrm{CH}_{3}, \mathrm{R}_{2}=\mathrm{H}, \mathrm{R}_{3}=\mathrm{H}$ $9 \mathrm{R}_{1}=\mathrm{C}\left(=\mathrm{CH}_{2}\right) \mathrm{CH}_{3}, \mathrm{R}_{2}=\mathrm{OH}, \mathrm{R}_{3}=\mathrm{H}$

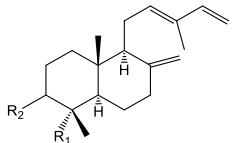

$18 \mathrm{R}_{1}=\mathrm{CH}_{2} \mathrm{OH}, \mathrm{R}_{2}=\mathrm{H}$ $19 \mathrm{R}_{1}=\mathrm{CHO}, \mathrm{R}_{2}=\mathrm{H}$ $20 R_{1}=\mathrm{COOH}, \mathrm{R}_{2}=\mathrm{H}$ $21 \mathrm{R}_{1}=\mathrm{CH}_{3}, \mathrm{R}_{2}=\beta-\mathrm{OH}$ $22 \mathbf{R}_{1}=\mathrm{CH}_{2} \mathrm{OH}, \mathbf{R}_{2}=\alpha-\mathrm{OH}$

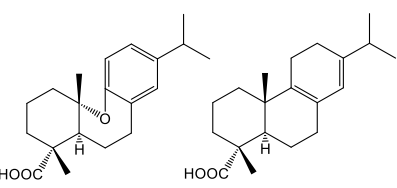

11
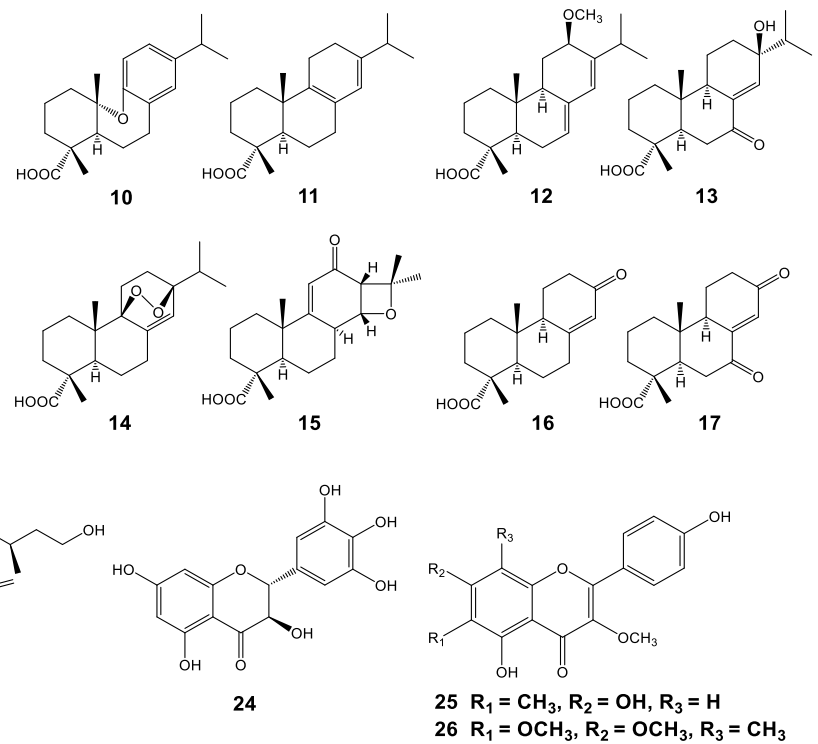

Figure 2. Chemical structures of compounds isolated from Pinus densiflora.

\subsection{Influenza Viral Inhibition and Structure-Activity Relationships (SARs) of Isolated Compounds from P. densiflora}

The 26 compounds isolated from $P$. densiflora (1-26) (Figure 1, Figure 2) were screened for their antiviral activities by using CPE inhibition and NA inhibition assays. As shown in Figure $3 \mathrm{~A}$ and Figure S22, compounds $5,6,8,10,13,16,17,20,23$, and 24 showed significant inhibition of the cytopathic effect induced by the influenza $\mathrm{H} 1 \mathrm{~N} 1$ virus at $10 \mu \mathrm{M}$ with ribavirin as a positive control. Especially, the inhibition activity of compound 5 was comparable to that of ribavirin at the same concentration. Interestingly, nine compounds out of the ten candidates are diterpenoids, and our results are very consistent with the antiviral activity results of some diterpenoids in previously reported papers [70-72]. On the other hand, compounds 24-26 were selected as strong candidates from the NA inhibition assay (Figure 3B). The flavonoid substances from $P$. densiflora inhibited NA, and these results can be effectively explained by previously reported studies about the structure-activity relationships (SARs) of compounds in the flavonoid class [73]. Compounds 5 and 24, which showed the strongest activity from the CPE inhibition assay and NA inhibition assay, respectively, were shown to have CPE inhibitory activity in a dose-dependent manner against the H1N1 and H9N2 subtypes (Figure 3C and Figure S23). From the assessment of effects on cell protection and viral particle neutralization, neither compound protected cells after they were preincubated in the cell protection assay, and they did not neutralize the virulent particles by direct binding (Figure S24). The effect of compound 5 on the cellular apoptosis in infected MDCK cells was also evaluated using flow cytometric analysis. As shown in Figure S27, the percent of apoptotic cells (Sub-G1) significantly decreased from 72.22 to 51.36 and $12.91 \%$ after treatment with compound 5 ( 5 and $20 \mu \mathrm{M}$, respectively). These results also suggest that compound 5 has antiviral activity, in part because it inhibits virus-induced cell apoptosis.

To discuss the structure-activity relationships (SARs) of diterpenoids isolated from the P. densiflora cortex and leaves, 21 compounds (3-23) were divided into three groups based on abietane-type tricyclic phenolic (3-10), tricyclic (11-17), and labdane-type bicyclic diterpenoids (18-23). Biological data of group 1 (3-10) (Figure 3A and Figure S22) indicated that the methoxylation at C-7 ( $\left.\mathrm{R}_{2}\right)$ could improve the antiviral properties and reduce the cytotoxicity (when comparing compound 5 with 3 and 4). Compounds 6-10, which replaced the isopropyl group with other groups, still maintained an 
antiviral effect. However, the presence of the hydroxy moiety at C-7 slightly increased the cytotoxicity (comparing compound 8 with 9). The antiviral profile of group 2 (11-17) indicated that the existence of one or two ketone groups at C-7 or C-13 significantly contributed to the anti-influenza activity of the abietane type (comparing compounds 13, 16, and 17 with 11, 12, 14, and 15). The final group (18-23) demonstrated that substitution of the carboxyl group at C-4 clearly increased H1N1 inhibition. However, replacement of the carboxyl moiety with other groups significantly reduced the antiviral properties, while the cytotoxicity significantly increased (comparing compounds 20 and 23 with 18, 19 and 21).
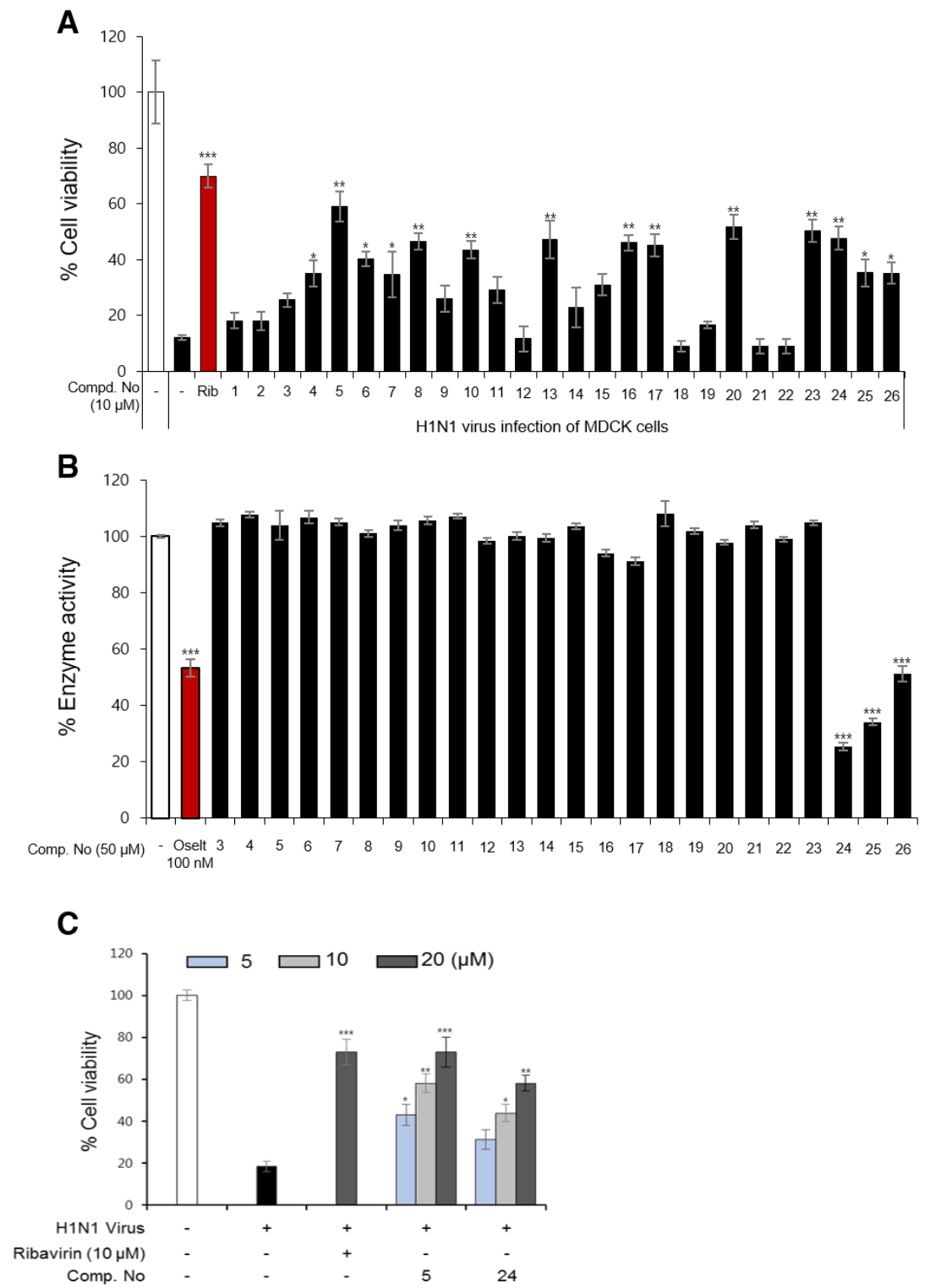

Figure 3. Antiviral activities of isolated compounds against the $H 1 N 1 \mathrm{~A} / \mathrm{PR} / 8 / 34$ virus in the cytopathic effect (CPE) inhibition and neuraminidase (NA) inhibition assays. (A) The percent cell survival was evaluated by the effects of all isolated compounds (1-26) and ribavirin (Rib), a positive control, at $10 \mu \mathrm{M}$ with the use of the CPE inhibition assay. (B) The inhibitory effects of compounds 3-26 at $50 \mu \mathrm{M}$ and oseltamivir (Oselt; $100 \mathrm{nM}$ ), a positive control, on NA from H1N1. (C) The influence of compounds 5 and $24(5,10$, and $20 \mu \mathrm{M})$ on cell viability was investigated using the CPE inhibition assay. Values are expressed as the mean \pm SD of three independent experiments, ${ }^{*} p<0.05,{ }^{* *} p<0.01$, and ${ }^{* * *} p<0.001$ compared to the virus control group (one-way analysis of variance followed by a two-tailed Student's t-test). 


\subsection{The Effects of Diterpenoids on mRNA and Protein Expression during H1N1 Replication}

During the viral life cycle, there are several proteins (NA, HA, matrix, NP) that play key roles for replication of the influenza virus. Therefore, inhibition of the synthesis of these proteins could be potentially promising targets for influenza antiviral drug discovery. Based on the CPE inhibition data in Figure 3A, some candidates (compounds 5, 8, 10, 20, 23 and 24) were obtained and screened for NA and HA expression by Western blot analysis. After $2 \mathrm{~h}$ of infection with the H1N1 virus, the cells were treated with the test compounds at various concentrations with ribavirin as a positive control. The changes in NA and HA expression were analyzed after $24 \mathrm{~h}$ of incubation. As shown in Figure 4A, compounds 5, 8, 10, 20 and 23 significantly decreased the protein expression of NA and HA, while compound 24 did not show clear inhibition. Compound $\mathbf{5}$ was also found to significantly decrease the production of NA and HA in a dose-dependent manner at 5, 10 and $20 \mu \mathrm{M}$. These aforementioned results were supported by an immunofluorescence assay (Figure 4B). The green fluorescence of tagged NA was significantly detected in the cell cytoplasm in the viral-infected cells, whereas the fluorescence was not detected in the noninfected cells. Interestingly, when H1N1-infected cells were treated with compound 5 at different concentrations $(5,10$, and $20 \mu \mathrm{M})$, the green fluorescence similarly decreased in the cell cytoplasm compared to the ribavirin-treated group $(10 \mu \mathrm{M})$. It was further confirmed by real-time PCR that compound 5 clearly reduced the mRNA expression of NA and HA at the early stage of the viral cycle (Figure 4C).

A

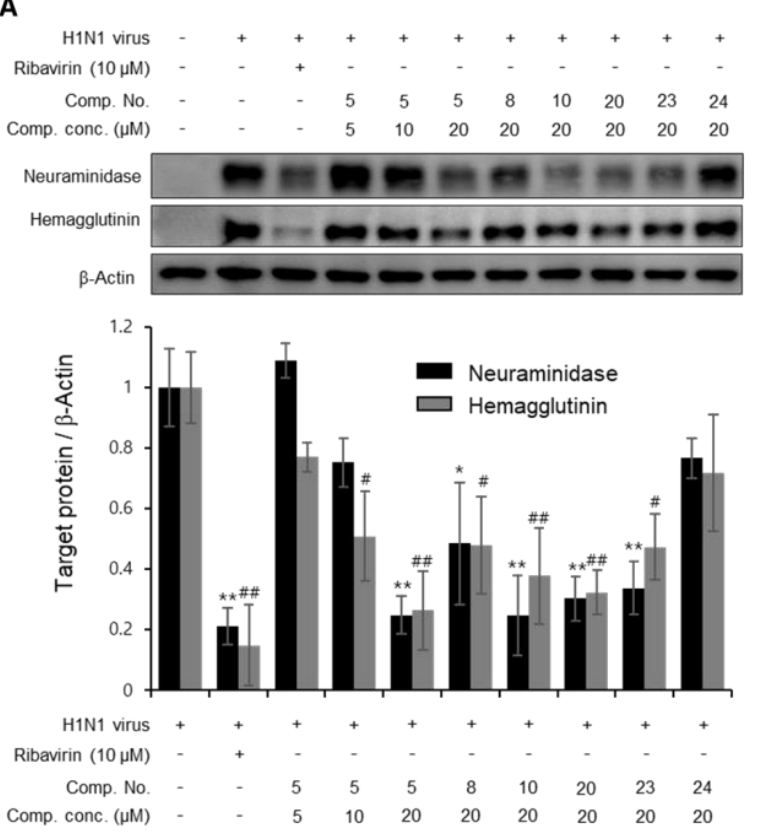

B
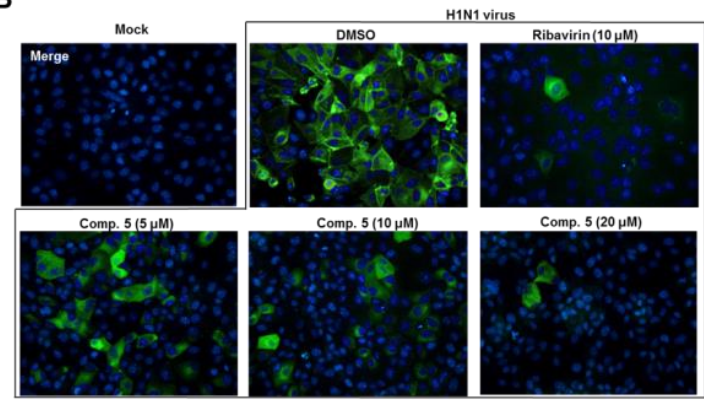

C

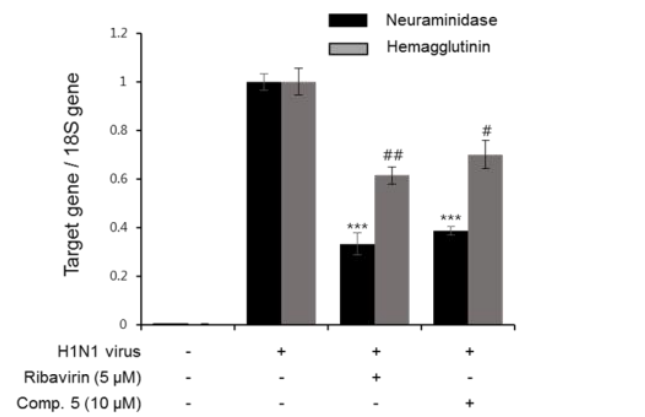

Figure 4. Relative mRNA and protein viral expression levels decreased after treatment with several compounds from P. densiflora. (A) Madin-Darby Canine Kidney (MDCK) cells were infected with the $\mathrm{H} 1 \mathrm{~N} 1$ virus for $2 \mathrm{~h}$ and then treated with compounds 5, 8, 10, 20, 23, and 24 at various concentrations. After $24 \mathrm{~h}$ of incubation, viral NA and HA were evaluated by Western blot analysis. Data are presented as the mean $\pm \operatorname{SD}(n=2-4),{ }^{*} p<0.05,{ }^{* *} p<0.01$, and \# $p<0.05, \# \# p<0.01$ compared to the NA and HA virus control groups, respectively. (B) Compound 5 reduced NA in the cytoplasm of viral-infected cells as measured by the immunofluorescence method. After infection with the H1N1 virus for $2 \mathrm{~h}$, MDCK cells were incubated with compound 5 or ribavirin as a positive control for $24 \mathrm{~h}$. The cells were then fixed, stained, and visualized using a fluorescence microscope. (C) Compound $\mathbf{5}$ decreased the mRNA levels of NA and HA induced by virus replication in MDCK cells as assessed by real-time PCR. Values are expressed as the mean $\pm \mathrm{SD}(n=3),{ }^{* * *} p<0.001$, and $\# p<0.05$, \#\# $p<0.01$ compared to the NA and HA virus control groups, respectively. 


\subsection{Detailed Neuraminidase Inhibition Assay of Compound $\mathbf{2 4}$ against Various Subtypes of Influenza A Virus}

Based on the screening data of the isolated compounds in Figure 3B, compound 24 was examined for detailed inhibitory NA activity [(including H1N1 A/PR/8/34 virus, H9N2 A/chicken/Korea/01210/2001 virus, wild-type (wt) pandemic $2009 \mathrm{H} 1 \mathrm{N1}$ virus (A/California/07/2009), oseltamivir-resistant virus (H274Y mutation)]. As shown in Table 2, compound 24 exhibited moderate activity on the percent NA activity, ranging from $35.34 \pm 0.97$ to $87.33 \pm 1.67 \%$ in a dose-dependent manner $(5,10$, and $20.0 \mu \mathrm{M})$. In brief, upon comparison of efficacy of compound 24 with that of oseltamivir, NA activity of H1N1 was inhibited by about $50 \%$ by $20 \mu \mathrm{M}$ of compound 24 , whereas oseltamivir inhibited around $50 \%$ at $100 \mathrm{nM}$. In case of NA of H9N2, NA activity was inhibited around 65\% upon treatment of compound 24 at $10 \mu \mathrm{M}$, whereas oseltamivir showed around 90\% of inhibitory activity even at $100 \mathrm{nM}$. Similarly, compound 24 showed around $40 \%$ enzyme inhibitory activity at $20 \mu \mathrm{M}$, whereas $60 \%$ of enzymatic activity was reduced by $100 \mathrm{nM}$ of oseltamivir. Based on our previously reported paper [32], the $\mathrm{IC}_{50}$ of oseltamivir against NA from $\mathrm{H} 274 \mathrm{Y}$ was $7.42 \pm 1.35 \mu \mathrm{M}$, which is consistent with our present data, but compound 24 inhibited around $53 \%$ of inhibitory activity at $20 \mu \mathrm{M}$. Notably, the inhibitory activity of oseltamivir $(100 \mathrm{nM})$ against the oseltamivir-resistant novel H1N1 (H275Y mutant) decreased greatly compared to the activity against H1N1 A/PR/8/34 and novel H1N1 (wt) (from $49.90 \pm 3.74$ and $38.57 \pm 4.32$ to $91.10 \pm 4.07 \%$, respectively), whereas compound 24 retained its inhibitory activity even against the oseltamivir-resistant novel H1N1 (from $48.40 \pm 1.35$ and $58.76 \pm 1.85$ to $57.22 \pm 1.11 \%$, respectively). Compound 24 was further assessed for its inhibitory mode against NA from H1N1 and H9N2 using a double-reciprocal Lineweaver-Burk plot. The result in Figure 5 shows that compound 24 was found to be a noncompetitive inhibitor in both enzyme subtypes (H1N1 and H9N2), because raising the concentration of substrate resulted in the convergence of lines that intersected at a nonzero point on the negative $x$-axis. Thus, compound 24 may allosterically interrupt NA activity that cleaves the binding between the sialic acid residues of the receptor of cells and a newly formed virion [74].

Table 2. Percent influenza NA activity (compared with DMSO as a control).

\begin{tabular}{ccccc}
\hline Comp. Name & H1N1 & H9N2 & H1N1 (wt) & H274Y \\
\hline DMSO & $100 \pm 2.69$ & $100 \pm 0.62$ & $100 \pm 1.04$ & $100 \pm 6.51$ \\
Oseltamivir $(100 \mathrm{nM})$ & $49.90 \pm 3.74$ & $10.79 \pm 0.18$ & $38.57 \pm 4.32$ & $91.10 \pm 4.07$ \\
Comp. 24 $(5 \mu \mathrm{M})$ & $75.93 \pm 1.17$ & $64.19 \pm 1.92$ & $87.33 \pm 1.67$ & $76.73 \pm 1.59$ \\
Comp. 24 $(10 \mu \mathrm{M})$ & $62.55 \pm 0.94$ & $49.79 \pm 1.74$ & $76.23 \pm 2.67$ & $72.38 \pm 6.96$ \\
Comp. 24 $(20 \mu \mathrm{M})$ & $48.40 \pm 1.35$ & $35.34 \pm 0.97$ & $58.76 \pm 1.85$ & $57.22 \pm 1.11$ \\
\hline
\end{tabular}

A

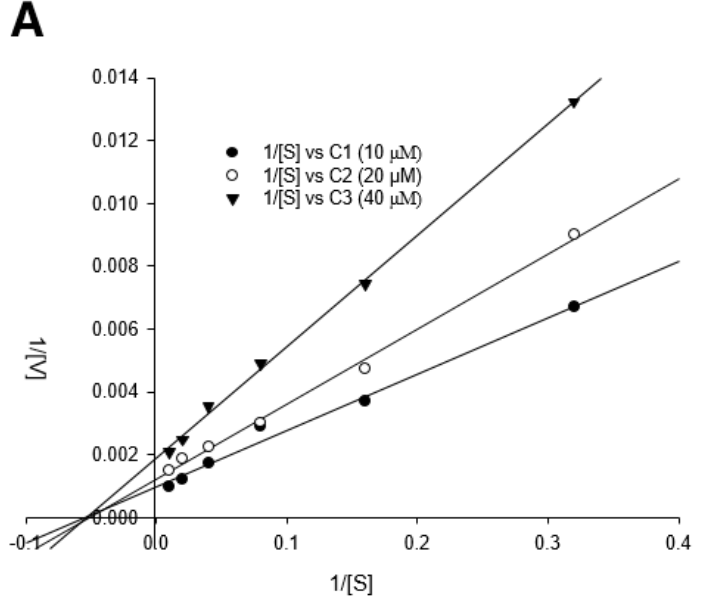

B

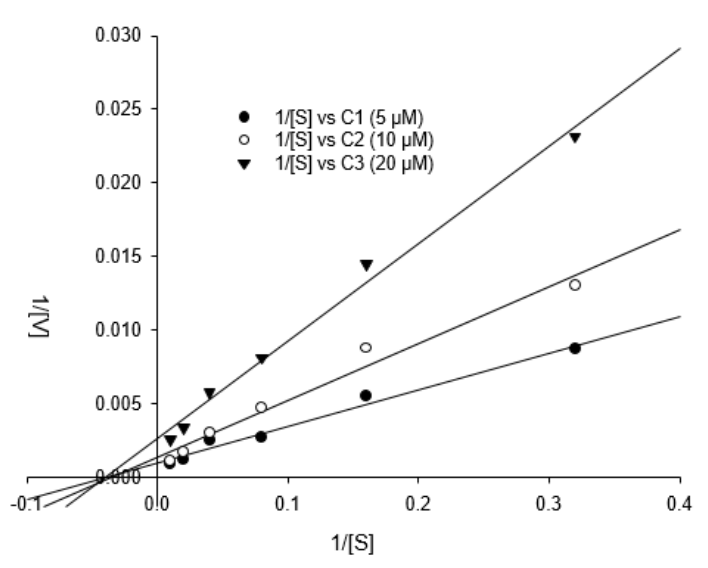

Figure 5. Inhibition mode of compound 24 on the NA H1N1/PR/8/34 and H9N2 A/Chicken/Korea/O1310/2001 enzymes. Lineweaver-Burk plots for the inhibition of compound 24 (A) at three concentrations $(\mathrm{C} 1=10 \mu \mathrm{M}, \mathrm{C} 2=20 \mu \mathrm{M}$, and $\mathrm{C} 3=40 \mu \mathrm{M})$ on NA from the H1N1 virus 
and $(\mathbf{B})$ at three other concentrations $(\mathrm{C} 1=5 \mu \mathrm{M}, \mathrm{C} 2=10 \mu \mathrm{M}$, and $\mathrm{C} 3=20 \mu \mathrm{M})$ on NA from the H9N2 virus for hydrolysis of the substrate. The values were analyzed in three replicates at each substrate concentration.

\subsection{Molecular Docking Simulation of Compounds $\mathbf{5}$ and $\mathbf{2 4}$ with Expected Target Proteins}

From the results in Figure 4, it is evident that compound $\mathbf{5}$ inhibits the synthesis of viral membrane proteins, HA and NA, but it is not obvious how this inhibition occurs. Therefore, molecular docking (MD) analysis was performed to predict which steps are disturbed for the inhibition of synthesis of HA and NA through binding affinity calculation and this MD analysis will serve as reference data for the future mechanistic in vitro studies. Since there are numerous target points in cascade reaction for the synthesis of two proteins and there become more relevant factors as the cascades proceeds further, it is advantageous to try first MD simulation with proteins in the upstream of the cascade, such as polymerase subunits and NP which are responsible for viral protein synthesis. Polymerase proteins including polymerase acidic protein (PA), polymerase basic protein 1 and 2 (PB1 and PB2), and NP, structural proteins of RNP particles play important roles in the life cycle of the influenza virus, such as during replication and transcription. NP is especially involved in RNP trafficking between the nucleus and cytoplasm and in the replication of RNPs and directly binds with M1, PB1, and PB2 [75,76]. Therefore, without NP, synthesis of all the viral proteins including HA and NA are ultimately prohibited via inhibition of mRNA transcription and vRNA replication. Moreover, previous studies have reported that the maximum amino acid difference of NP among influenza A strains was less than $11 \%$, which makes NP as a potential therapeutic target for the treatment of all influenza virus strains [77]. In addition to NP, after polymerase subunits (PA, PB1, and PB2) are newly synthesized via initial mRNA expression and imported back into nucleus, each subunit plays its own distinct roles in mRNA/vRNA transcription. PB1 subunit serves as a place where complementary RNA (cRNA) is elongated [78]. Also, in the cap snatching step, which is a crucial for mRNA transcription, PB2 and PA are used for binding $5^{\prime}$ cap of a host mRNA and cleaving nucleotides of the $5^{\prime}$ cap, respectively $[79,80]$. Considering the results in Figure 4 and importance of NA and polymerase subunits in terms of synthesis of HA and NA, we investigated whether compound 5 can be docked to polymerase proteins and NP of influenza virus. According to the data in the Protein Data Bank (PDB), the binding pocket between the active ligand 4-(2-chloro-4-nitrophenyl)piperazin-1-yl][3-(2-methoxyphenyl)-5-methyl-1,2-oxazol-4-yl]methanone (LGH) and NP (PDB ID: 3RO5) showed stable interaction energy at residues Arg305, Ser376, Tyr52, Tyr289, and Arg99 [41] (Figure 6). In our study, compound 5 showed several interactions with Arg305, Ser376, Tyr52, Trp104, Arg99, Tyr289, Typ313, and Glu294 in active site AC1 with a low CDOCKER energy and CDOCKER interaction energy $(-17.2458$ and $-40.9050 \mathrm{kcal} / \mathrm{mol}$, respectively; Tables S1 and S2).

In addition to the NP complex, docking analysis of 5 with the structures of the C-terminal region of PA (PAC) complexed with a peptide from PB1 was carried out. A previous report suggested that residues Met1, Val3, Asn4, Pro5, Leu7, Leu8, Phe9, and Leu10 on the PB1 peptide are important key residues for interactions with PA and show the lowest binding free energy [42]. In order to determine the mechanism of binding of $\mathbf{5}$ with PA-PB1 polymerase, the interactions of compound $\mathbf{5}$ and the polymerase complex (PDB ID: 2ZNL) were identified at residues Pro5, Phe9, Lys643, Gln591, Phe658, Phe707, Leu666, and Arg663 with a low CDOCKER energy and CDOCKER interaction energy (-7.5123 and $-32.6849 \mathrm{kcal} / \mathrm{mol}$, respectively; Figure 6 and Tables S1 and S2). When comparing CDOCKER energy values of two docking enzymes of compound 5 , it is likely that compound 5 binds with NP in a more stable manner than with PA-PB1. 


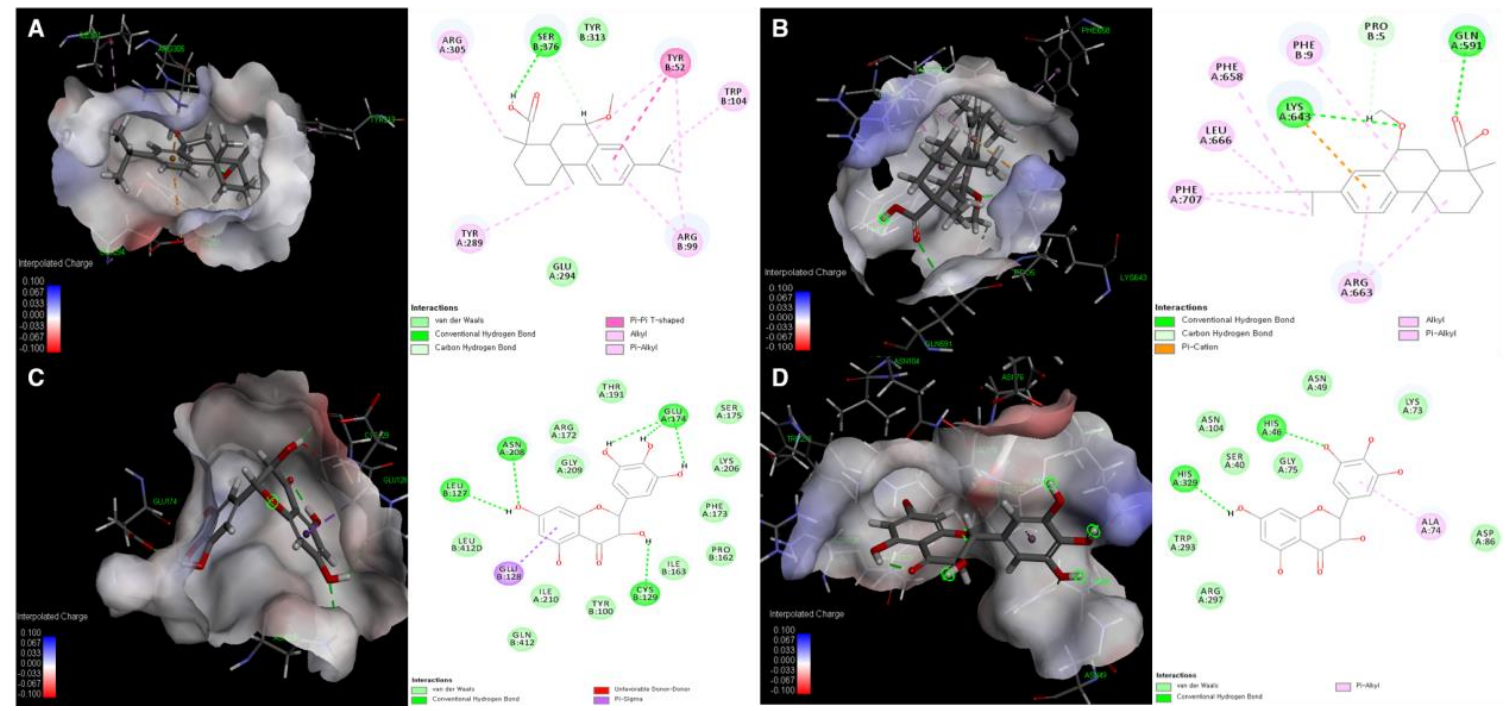

Figure 6. Illustration of the molecular docking simulation and 2D diagram of the interactions between (A) NP and compound 5, (B) PA-PB1 and compound 5, (C) NA and compound 24, and (D) NA mutant and compound 24 using Discovery Studio Client v19.1.0.18287/CDOCKER software. The structures of the proteins were obtained from the Protein Data Bank (http://www.pdb.org) (PDB ID code: 3RO5, 2ZNL, 3TI4, and 3CL0 for A-D, respectively).

Based on the data in Figure 3B and Table 2, in which compound 24 showed strong NA inhibitory activity against four types of IVA, docking analysis of $\mathbf{2 4}$ with NA (PDB ID: 3TI4) [43] and its mutant (PDB ID: 3CL0) [44] was implemented. Since results in Figure 5 clearly indicated that compound 24 inhibits neuraminidase in a noncompetitive manner, in other words, it binds to allosteric sites, docking sites were obtained by defining binding sites from receptor cavities of whole structures of the enzyme to perform blind docking experiments. As shown in Figure 6, Figure S28 and Tables S1-S3, compound 24 showed stable docking with nine binding sites out of 21 sites. Among the nine binding sites, compound 24 bound to site 1 with the lowest CDOCKER energy $(-38.5234 \mathrm{kcal} / \mathrm{mol})$, which means its binding is fairly stable compared to the value of docking of laninamivir octanoate (positive control). Although interaction amino acid residues from both cases cannot be compared with each other since laninamivir octanoate inhibits the NA in a competitive manner, only CDOCKER energy and CDOCKER interaction energy could be compared to see how the docking of our compound 24 is stable. It binds to Glu174, Asn208, Leu127, and Cys129 via conventional hydrogen bonds and with Glu128 via pi-sigma interaction (Figure 6). On the other hand, compound $\mathbf{2 4}$ was stably docked to four binding sites of NA mutant out of seven sites (Figure 6 and Tables S1, S2, and S4). Among them, the compound was successfully docked to site 6 with the lowest energy of CDOCKER energy $(-24.4057 \mathrm{kcal} / \mathrm{mol}$ ) compared to that of docking of oseltamivir (Figure S28). It interacts with His46 and His329 via a conventional hydrogen bond and has pi-alkyl interaction with Ala74 residue of the enzyme (Figure 6). Taken together, the MD analysis of compound 5 with NP and PA-PB1 suggests that it may have inhibitory influences on NP rather than on PA-PB1 and serves as reference for the future in vitro assay to verify. Also, the result of MD analysis of compound $\mathbf{2 4}$ supports its strong inhibitory activity toward NA and NA mutant and suggests the possible allosteric interaction residues of enzymes.

\subsection{Anti-Inflammatory Effects of the Isolated Compounds}

Combination chemotherapy between NA inhibitors and anti-inflammatory agents may become a new strategy against drug resistance in patients with influenza viral infections. Previous studies have reported that during influenza viral infections, proinflammatory cytokines and nitric oxide (NO) production could be excessive in macrophages. In this study, we evaluated the ability of isolated 
compounds from $P$. densiflora to suppress the production of $\mathrm{NO}$ and inducible nitric oxide synthase (iNOS) expression in RAW cells. As shown in Figure 7A and Figure S25, compounds 5 and 24 did not show cytotoxicity at $30 \mu \mathrm{M}$ and inhibited NO production in a dose-dependent manner at 5, 10, and $20 \mu \mathrm{M}$ in RAW cells stimulated with $100 \mathrm{ng} / \mathrm{mL}$ LPS. This tendency was reproduced in RAW cells upon viral infection. In our preliminary experiments with low MOI 0.01 infections of the H1N1 $\mathrm{A} / \mathrm{PR} / 8 / 34$ virus, $\mathrm{NO}$ production was low and inconsistent (Figure S26). Therefore, infections with a high MOI 1.0 were implemented. As shown in Figure 7B, with a high MOI 1 infection, NO production was 11-fold higher than that in the low MOI 0.01 infections. Moreover, NO production was clearly reduced in the presence of compounds 5 and $24(20 \mu \mathrm{M})$. Moreover, the expression of iNOS significantly decreased when stimulated RAW cells were treated with these compounds at the concentration of $20 \mu \mathrm{M}$ (Figure 7C). Based on the above data, we gained insight into the effects of the two compounds on the inhibition of NO production. Considering the high mortality induced by complications such as secondary bacterial pneumonia and otitis media following influenza infection, prevention of excessive inflammatory responses is also important. It has been demonstrated that severe IAV infection can give rise to pulmonary infiltration and hypoxemia that ultimately leads to acute respiratory distress syndrome (ARDS), the major contributor to severe mortality [81]. Pathophysiologically, it has been shown that inflammation upon viral infection occurs to adapt to the body by increasing body temperature and recruiting monocytes/macrophages in order to resist and fight against invasion as a normal defensive mechanism. However, it is possible that the immune system of our body releases excessive levels of proinflammatory cytokines and chemokines. A strong Th1-type immune response stimulated by proinflammatory cytokines, such as TNF- $\alpha$ and IL- $1 \beta$, causes tissue damage [82,83]. Although detailed experiments, such as the effects on the aforementioned cytokines in lung or spleen tissue, are needed, our results indicated that compounds $\mathbf{5}$ and $\mathbf{2 4}$ from $P$. densiflora can effectively inhibit not only viral growth in MDCK cells but also NO production by multitargeting.

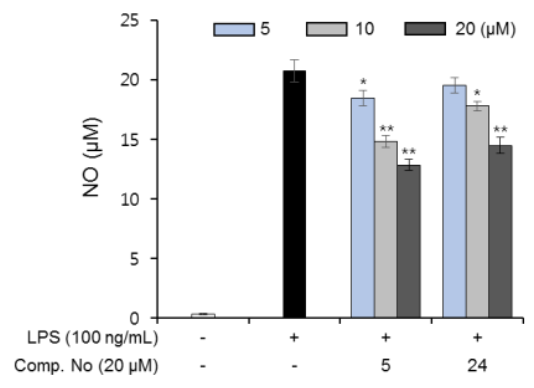

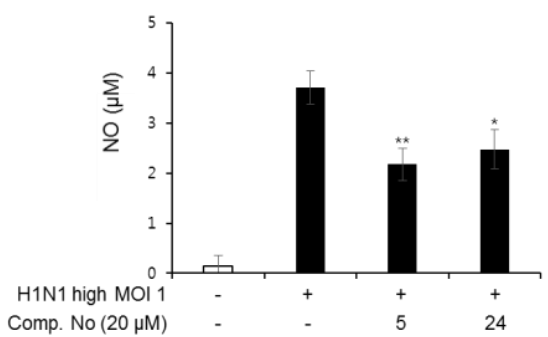

\section{c}

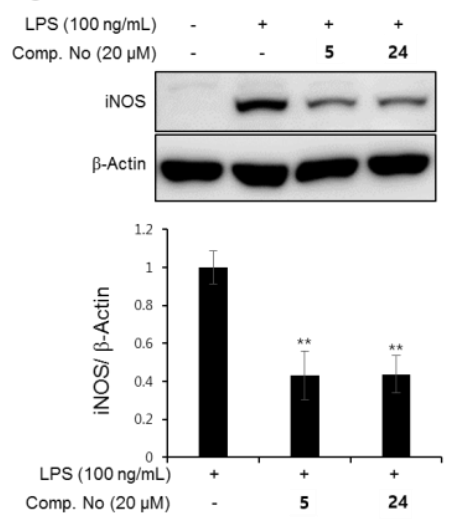

Figure 7. Effects of compounds 5 and 24 on NO production and iNOS expression in RAW 264.7 cells. Treatment of the test compounds at various concentrations to inhibit NO production in RAW 264.7 cells by either (A) $100 \mathrm{ng} / \mathrm{mL}$ LPS treatment or (B) H1N1 A/PR/8/34 viral infection. (C) Western blot analysis of iNOS expression in activated RAW 264.7 cells decreased by compounds 5 and 24 at $20 \mu \mathrm{M}$. Data are presented as the mean $\pm \operatorname{SD}(n=3),{ }^{*} p<0.05,{ }^{* *} p<0.01$, compared to the positive control group.

\section{Conclusions}

Taken together, 26 compounds, including two new megastigmane glycosides, 23 diterpenoids, and three flavonoids, were isolated from the cortex and leaves of P. densiflora. Whole compounds were evaluated for their CPE and NA inhibitory properties, which in turn allowed us to anticipate SAR information. Some candidates that showed potent activity were selected and subjected to various detailed mechanistic studies to identify the mode of action, such as effects on mRNA expression, cellular apoptosis, neutralization of viral particles, cell protection against viral infection and inhibition 
of inflammation. While flavonoids exerted their anti-influenza activity via direct NA inhibition, the diterpenes isolated here are likely to affect the gene expression of various proteins that are essential for viral propagation rather than direct neutralization of surface proteins. Moreover, considering that compound 5 exhibited anti-inflammatory activity, other isolated diterpenes may also have that activity. To date, this study demonstrates that $P$. densiflora can be considered an abundant natural anti-influenza viral source to find new bioactive compounds against influenza virus outbreaks in the future.

Supplementary Materials: The following are available online at http://www.mdpi.com/2218-273X/10/5/711/s1. Figure S1: Isolation scheme of the compounds from the leaves of Pinus densiflora. Figure S2: Isolation scheme of the compounds from the cotex of Pinus densiflora. Figure S3: HRESIMS data of compound 1. Figure S4: ${ }^{1} \mathrm{H}$ NMR spectrum (methanol- $d_{4}, 500 \mathrm{MHz}$ ) of compound 1. Figure S5: ${ }^{13} \mathrm{C}$ NMR spectrum (methanol- $d_{4}, 125 \mathrm{MHz}$ ) of compound 1. Figure S6: HMBC spectrum (methanol- $d_{4}, 500 \mathrm{MHz}$ ) of compound 1. Figure S7: COSY spectrum (methanol- $d_{4}, 500 \mathrm{MHz}$ ) of compound 1. Figure S8: HRESIMS data of compound 2. Figure S9: ${ }^{1} \mathrm{H}$ NMR spectrum (methanol- $d_{4}, 500 \mathrm{MHz}$ ) of compound 2. Figure S10: ${ }^{13} \mathrm{C}$ NMR spectrum (methanol- $d_{4}, 125 \mathrm{MHz}$ ) of compound 2. Figure S11: HMBC spectrum (methanol- $d_{4}, 500 \mathrm{MHz}$ ) of compound 2. Figure S12: COSY spectrum (methanol- $d_{4}, 500 \mathrm{MHz}$ ) of compound 2. Figure S13: HRESIMS data of compound 2a. Figure S14: ${ }^{1} \mathrm{H}$ NMR spectrum (methanol- $d_{4}, 400 \mathrm{MHz}$ ) of compound 2a. Figure S15: ${ }^{13} \mathrm{C}$ NMR spectrum (methanol- $\left.d_{4}, 100 \mathrm{MHz}\right)$ of compound 2a. Figure S16: HSQC NMR spectrum (methanol- $d_{4}, 400 \mathrm{MHz}$ ) of compound 2a. Figure S17: HRESIMS data of compound $\mathbf{2 b}$. Figure S18: HRESIMS data of compound 2c. Figure S19: ${ }^{1} \mathrm{H} \mathrm{NMR} \mathrm{spectrum}\left(\mathrm{CDCl}_{3}\right.$, $600 \mathrm{MHz})$ of compound $\mathbf{2 b}$ and $2 \mathrm{c}$. Figure S20: COSY spectrum $\left(\mathrm{CDCl}_{3}, 600 \mathrm{MHz}\right)$ of compound $2 \mathbf{b}$ and $2 \mathrm{c}$. Figure S21: Comparison of chromatograms after sugar analysis for the determination of absolute configuration of sugar moiety in compound $\mathbf{1}$ and 2. Figure S22: Percent cell viability evaluated by the effects of all compounds (1-26) at $10 \mu \mathrm{M}$ using cytotoxicity assay. Figure S23: Inhibition of cytopathic effect of compounds 5 and 24 against H9N2 virus. Figure S24: The effects of compounds 5 and 24 on the cell protection from viral infection and the H1N1 particles. Figure S25: Percent cell viability of RAW 264.7 cells evaluated by the effects of compounds 5 and 24 at $30 \mu \mathrm{M}$ using cytotoxicity assay. Figure S26: Effects of compounds $\mathbf{5}$ and $\mathbf{2 4}$ on the NO production in infected-RAW 264.7 cells with low MOI. Figure S27: The effects of compound 5 on the cellular DNA contents after H1N1 virus infection. Figure S28: Images of global representation of NA surface with selected docking sites for compound 24. Table S1: CDOCKER and CDOCKER interaction energies of compounds $\mathbf{5}$ and 24 with nucleoprotein, PA-PB1 polymerase, neuraminidase, and neuraminidase mutant. Table S2: Molecular docking and interaction images of positive control with nucleoprotein, neuraminidase, and neuraminidase mutant. Table S3: CDOCKER and CDOCKER interaction energies of compounds 24 with neuraminidase. Table S4: CDOCKER and CDOCKER interaction energies of compounds 24 with neuraminidase mutant. Table S5: Primers used for real-time PCR. Supporting NMR data of isolated compounds.

Author Contributions: T.K.Q.H. and T.V. designed and performed the biological experiments. B.W.L. determined the absolute configurations of the two new compounds by performing the modified Mosher's analysis and sugar analysis and also wrote the manuscript. N.H.N. performed the isolation of the whole compounds and determined their structures. H.M.C. and T.P.D. aided in fractionation, isolation and characterization of the compounds from P. densiflora. E.K. purified and provided virus stocks of two subtypes of the influenza virus. W.K.O. designed the research and is also the corresponding author. All authors have read and agreed to the published version of the manuscript.

Funding: This work was supported financially by grants from the Korea Bioactive Natural Material Bank (NRF-2017M3A9B8069409) through the National Research Foundation of Korea funded by the Ministry of Science and ICT and from the Korea Institute of Planning and Evaluation for Technology in Food, Agriculture and Forestry (IPET) through the Animal Disease Management Technology Development Program funded by the Ministry of Agriculture, Food and Rural Affairs (MAFRA) (318031031SB010) from the Korean government.

Conflicts of Interest: The authors declare no conflict of interest.

\section{References}

1. Paget, J.; Spreeuwenberg, P.; Charu, V.; Taylor, R.J.; Iuliano, A.D.; Bresee, J.; Simonsen, L.; Viboud, C. Global mortality associated with seasonal influenza epidemic: New burden estimates and predictors from the GLaMOR project. J. Glob. Health 2019, 9, 020421. [CrossRef] [PubMed]

2. Mansoor, S.; Maqbool, I. Swine flu a seasonal pandemic, symptoms, diagnostics and prevention. Rev. Med. Microbiol. 2019, 30, 200-204. [CrossRef]

3. Uyeki, T.M.; Peiris, M. Novel avian influenza A virus infections of humans. Infect. Dis. Clin. North Am. 2019, 33, 907-932. [CrossRef] [PubMed]

4. Shie, J.-J.; Fang, J.-M. Development of effective anti-influenza drugs: Congeners and conjugates-A review. J. Biomed. Sci. 2019, 84, 1-20. [CrossRef] [PubMed] 
5. Both, G.W.; Sleigh, M.J.; Cox, N.J.; Kendal, A.P. Antigenic drift in influenza virus H3 hemagglutinin from 1968 to 1980: Multiple evolutionary pathways and sequential amino acid changes at key antigenic sites. J. Virol. 1983, 48, 52-60. [CrossRef] [PubMed]

6. Styk, B.; Russ, G.; Pola'kova, K. Antigenic glycopolypeptides HA1 and HA2 of influenza virus hemagglutinin. III. Reactivity with human convalescent sera. Acta Virol. 1979, 23, 1-8.

7. Gocník, M.; Fislová, T.; Mucha, V.; Sládková, T.; Russ, G.; Kostolanský, F.; Varečková, E. Antibodies induced by the HA2 glycopolypeptide of influenza virus haemagglutinin improve recovery from influenza A virus infection. J. Gen. Virol. 2008, 89, 958-967. [CrossRef]

8. Lin, D.; Luo, Y.; Yang, G.; Li, F.; Xie, X.; Chen, D.; He, L.; Wang, J.; Ye, C.; Lu, S.; et al. Potent influenza A virus entry inhibitors targeting a conserved region of hemagglutinin. Biochem. Pharmacol. 2017, 144, 35-51. [CrossRef]

9. Shi, W.-Z.; Jiang, L.-Z.; Song, G.-P.; Wang, S.; Xiong, P.; Ke, C.-W. Study on the antiviral activities and hemagglutinin-based molecular mechanism of novel chlorogenin 3-O- $\beta$-chacotrioside derivatives against H5N1 subtype viruses. Viruses 2020, 12, 304. [CrossRef]

10. Kosono, S.; Kasai, A.; Komaba, S.; Matsubara, T.; Sato, T.; Takahashi, D.; Toshima, K. Novel hemagglutinin-binding sulfated oligofucosides and their effect on influenza virus infection. Chem. Commun. 2018, 54, 7467. [CrossRef]

11. Kadam, R.U.; Wilson, I.A. Structural basis of influenza virus fusion inhibition by the antiviral drug Arbidol. Proc. Natl. Acad. Sci. USA 2017, 114, 206-214. [CrossRef] [PubMed]

12. Leneva, I.A.; Falynskova, I.N.; Makhmudova, N.R.; Poromov, A.A.; Yatsyshina, S.B.; Maleev, V.V. Umifenovir susceptibility monitoring and characterization of influenza viruses isolated during ARBITR clinical study. J. Med. Virol. 2019, 91, 588-597. [CrossRef] [PubMed]

13. Davidson, S. Treating influenza infection, from now and into the future. Front. Immunol. 2018, 9. [CrossRef] [PubMed]

14. Barik, S. New treatments for influenza. BMC Med. 2012, 10, 104. [CrossRef]

15. Hurt, A.C. Antiviral therapy for the next influenza pandemic. Trop. Med. Infect. Dis. 2019, 4. [CrossRef]

16. Kim, N.-Y.; Jang, M.-K.; Lee, D.-G.; Yu, K.-H.; Jang, H.J.; Kim, M.; Kim, S.G.; Yoo, B.H.; Lee, S.-H. Comparison of methods for proanthocyanidin extraction from pine (Pinus densiflora) needles and biological activities of the extracts. Nutr. Res. Pract. 2020, 4, 16-22. [CrossRef]

17. Hur, J. Dongeubogam; Dongeuhak Institute, Ryo-gang Pub. Co.: Seoul, Korea, 1994.

18. Li, S. Compendium of Materia Medica (Bencao Gangmu); Huaxia Press: Beijing, China, 2012; (1593 republished in 2012).

19. The Korean Herbal Pharmacopoeia; Food and Drug Administration: Seoul, Korea, 2020.

20. Kim, Y.S.; Shin, D.H. Volatile components and antibacterial effects of pine needle (Pinus densiflora S. and Z.) extracts. Food Microbiol. 2005, 22, 37-45. [CrossRef]

21. Chun, H.S.; Kim, J.-M.; Choi, E.H.; Chang, N. Neuroprotective effects of several Korean medicinal plants traditionally used for stroke remedy. J. Med. Food 2008, 11, 246-251. [CrossRef]

22. Park, G.; Paudyal, D.P.; Hwang, I.; Tripathi, G.R.; Yang, Y.; Cheong, H. Production of fermented needle extracts from red pine and their functional characterization. Biotechnol. Bioprocess Eng. 2008, 13, $256-261$. [CrossRef]

23. Kwak, C.S.; Moon, S.C.; Lee, M.S. Antioxidant, antimutagenic, and antitumor effects of pine needles (Pinus densiflora). Nutr. Cancer 2006, 56, 162-171. [CrossRef]

24. Arbuthnot, P. Antiviral Drugs: Aspects of Clinical Use and Recent Advances; InTech: Rijeka, Croatia, $2012 ;$ p. 180.

25. Kim, Y.J.; Cho, B.J.; Ko, M.S.; Jung, J.M.; Kim, H.R.; Song, H.S.; Lee, J.Y.; Sim, S.S.; Kim, C.J. Anti-oxidant and anti-aging activities of essential oils of Pinus densiflora needles and twigs. Yakhak Hoeji 2010, 54, 215-225.

26. Jung, M.J.; Jung, H.A.; Kang, S.S.; Hwang, G.S.; Choi, J.S. A new abietic acid-type diterpene glucoside from the needles of Pinus densiflora. Arch. Pharm. Res. 2009, 32, 1699-1704. [CrossRef] [PubMed]

27. Lee, S.K.; Lee, H.J.; Min, H.Y.; Park, E.J.; Lee, K.M.; Ahn, Y.H.; Cho, Y.J.; Pyee, J.H. Antibacterial and antifungal activity of pinosylvin, a constituent of pine. Fitoterapia 2005, 76, 258-260. [CrossRef] [PubMed]

28. Sultan, M.Z.; Jeon, Y.-M.; Moon, S.-S. Labdane-type diterpenes active against acne from pine cones (Pinus densiflora). Planta Med. 2008, 74, 449-452. [CrossRef] [PubMed]

29. Tang, Y.; Yu, B.; Hu, J.; Wu, T.; Hui, H. Three new homoisoflavanone glycosides from the bulbs of Ornithogalum caudatum. J. Nat. Prod. 2002, 65, 218-220. [CrossRef] [PubMed] 
30. Hoye, T.R.; Jeffrey, C.S.; Shao, F. Mosher ester analysis for the determination of absolute configuration of stereogenic (chiral) carbinol carbons. Nat. Protoc. 2007, 2, 2451-2458. [CrossRef]

31. Tanaka, T.; Nakashima, T.; Ueda, T.; Tomii, K.; Kouno, I. Facile discrimination of aldose enantiomers by reversed-phase HPLC. Chem. Pharm. Bull. 2007, 55, 899-901. [CrossRef]

32. Ha, T.K.Q.; Dao, T.T.; Nguyen, N.H.; Kim, J.; Kim, E.; Cho, T.O.; On, W.K. Antiviral phenolics from the leaves of Cleistocalyx operculatus. Fitoterapia 2016, 110, 135-141. [CrossRef]

33. Kim, S.H.; Ha, T.K.Q.; Oh, W.K.; Shin, J.; Oh, D.-C. Antiviral indolosesquiterpenoid xiamycins C-E from a halophilic actinomycete. J. Nat. Prod. 2016, 79, 51-58. [CrossRef]

34. Cho, H.M.; Doan, T.P.; Ha, T.K.Q.; Kim, H.W.; Lee, B.W.; Pham, H.T.T.; Cho, T.O.; Oh, W.K. Dereplication by high-performance liquid chromatography (HPLC) with quadrupole-time-of-flight mass spectroscopy (qTOF-MS) and antiviral activities of phlorotannins from Ecklonia cava. Mar. Drugs 2019, 17, 149. [CrossRef]

35. Miyamoto, D.; Kusagaya, Y.; Endo, N.; Sometani, A.; Takeo, S.; Suzuki, T.; Arima, Y.; Nakajima, K.; Suzuki, Y. Thujaplicin-copper chelates inhibit replication of human influenza viruses. Antivir. Res. 1998, 39, 89-100. [CrossRef]

36. Dao, T.-T.; Tung, B.-T.; Nguyen, P.-H.; Thuong, P.-T.; Yoo, S.-S.; Kim, E.-H.; Kim, S.-K.; Oh, W.-K. C-methylated flavonoids from Cleistocalyx operculatus and their inhibitory effects on novel influenza A(H1N1) neuraminidase. J. Nat. Prod. 2010, 73, 1636-1642. [CrossRef] [PubMed]

37. Theisen, L.L.; Muller, C.P. EPs ${ }^{\circledR} 7630$ (Umckaloabo ${ }^{\circledR}$ ), an extract from Pelargonium sidoides roots, exerts anti-influenza virus activity in vitro and in vivo. Antivir. Res. 2012, 94, 147-156. [CrossRef] [PubMed]

38. Cecil, C.E.; Davis, J.M.; Cech, N.B.; Laster, S.M. Inhibition of H1N1 influenza A virus growth and induction of inflammatory mediators by the isoquinoline alkaloid berberine and extracts of goldenseal (Hydrastis canadensis). Int. Immunopharmacol. 2011, 11, 1706-1714. [CrossRef]

39. Miranda, K.M.; Espey, M.G.; Wink, D.A. A rapid, simple spectrophotometric method for simultaneous detection of nitrate and nitrite. Nitric Oxide 2001, 5, 62-71. [CrossRef]

40. Yaeghoobi, M.; Frimayanti, N.; Chee, C.F.; Ikram, K.K.; Najjar, B.O.; Zain, S.M.; Abdullah, Z.; Wahab, H.A.; Rahman, N.A. QSAR, in silico docking and in vitro evaluation of chalcone derivatives as potential inhibitors for H1N1 virus neuraminidase. Med. Chem. Res. 2016, 25, 2133-2142. [CrossRef]

41. Gerrits, S.W.; Cianci, C.; Kim, S.; Pearce, B.C.; Deminie, C.; Discotto, L.; McAuliffe, B.; Minassian, B.F.; Shi, S.; $\mathrm{Zhu}$, S.; et al. Inhibition of influenza virus replication via small molecules that induce the formation of higher-order nucleoprotein oligomers. Proc. Natl. Acad. Sci. USA 2011, 108, 15366-15371. [CrossRef]

42. Obayashi, E.; Yoshida, H.; Kawai, F.; Shibayama, N.; Kawaguchi, A.; Nagata, K.; Tame, J.R.H.; Park, S.-Y. The structural basis for an essential subunit interaction in influenza virus RNA polymerase. Nature 2008, 454, 1127-1131. [CrossRef]

43. Vavricka, C.J.; Li, Q.; Wu, Y.; Qi, J.; Wang, M.; Liu, Y.; Gao, F.; Liu, J.; Feng, E.; He, J.; et al. Structural and functional analysis of laninamivir and its octanoate prodrug reveals group specific mechanisms for influenza NA inhibition. PLoS Pathog. 2011, 7. [CrossRef]

44. Collins, P.J.; Haire, L.F.; Lin, Y.P.; Liu, J.; Russell, R.J.; Walker, P.A.; Skehel, J.J.; Martin, S.R.; Hay, A.J.; Gamblin, S.J. Crystal structures of oseltamivir-resistant influenza virus neuraminidase mutants. Nature 2008, 453, 1258-1261. [CrossRef]

45. Otsuka, H.; Tamaki, A. Platanionosides D-J: Megastigmane glycosides from the Leaves of Alangium platanifolium (SIEB. Et ZUCC.) HARMS var. platanifolium. Chem. Pharm. Bull. 2002, 50, 390-394. [CrossRef] [PubMed]

46. Agrawal, P. NMR spectroscopy in the structural elucidation of oligosaccharides and glycosides. Phytochemistry 1992, 31, 3307-3330. [CrossRef]

47. Kasai, R.; Suzuo, M.; Asakawa, J.; Tanaka, O. Carbon-13 chemical shifts of isoprenoid- $\beta$-D-glucopyranosides and - $\beta$-D-mannopyranosides. Stereochemical influences of aglycones alcohols. Tetrahedron Lett. 1977, 2, 175-178. [CrossRef]

48. Corral, J.M.M.D.; Gordaliza, M.; Salinero, M.A.; San Feliciano, A. ${ }^{13}$ C NMR data for abieta-8,11,13-triene diterpenoids. Magn. Reson. Chem. 1994, 32, 774-781. [CrossRef]

49. Kinouchi, Y.; Ohtsu, H.; Tokuda, H.; Nishino, H.; Matsunaga, S.; Tanaka, R. Potential antitumor-promoting diterpenoids from the stem bark of Picea glehni. J. Nat. Prod. 2000, 63, 817-820. [CrossRef]

50. Wu, L.; Li, Y.-L.; Li, S.-M.; Yang, X.-W.; Xia, J.-H.; Zhou, L.; Zhang, W.-D. Systematic phytochemical investigation of Abies spectabilis. Chem. Pharm. Bull. 2010, 58, 1646-1649. [CrossRef] [PubMed] 
51. Cheung, H.T.A.; Miyase, T.; Lenguyen, M.P.; Smal, M.A. Further acidic constituents and neutral components of Pinus massoniana Resin. Tetrahedron 1973, 49, 7903-7915. [CrossRef]

52. Yang, X.-W.; Li, S.-M.; Feng, L.; Shen, Y.-H.; Tian, J.-M.; Liu, X.-H.; Zeng, H.-W.; Zhang, C.; Zhang, W.-D. Abiesanordines A-N: Fourteen new norditerpenes from Abies georgei. Tetrahedron 2008, 64, 4354-4362. [CrossRef]

53. Tanaka, R.; Ohtsu, H.; Matsunaga, S. Abietane diterpene acids and other constituents from the leaves of Larix kaempferi. Phytochemistry 1997, 46, 1051-1057. [CrossRef]

54. Georges, P.; Legault, J.; Lavoie, S.; Grenon, C.; Pichette, A. Diterpenoids from the buds of Pinus banksiana Lamb. Molecules 2012, 17, 9716-9727. [CrossRef]

55. Ohtsu, H.; Tanaka, R.; Matsunaga, S.; Tokuda, H.; Nishino, H. Anti-tumor-promoting rearranged abietane diterpenes from the leaves of Larix kaempferi. Planta Med. 1999, 65, 664-966. [CrossRef] [PubMed]

56. Landucci, L.L.; Zinkel, D.F. The ${ }^{1} \mathrm{H}$ and ${ }^{13} \mathrm{C}$ NMR spectra of the abietadienoic resin acids. Holzforschung 1991, 45, 341-346. [CrossRef]

57. Zhang, Y.-M.; Gong, Q.-F.; Yang, J.-Q.; Zeng, G.-Z.; Tan, N.-H. Antioxidant constituents from Pinus massoniana. Plant Divers. Resour. 2013, 35, 209-215.

58. Ohtsu, H.; Tanaka, R.; In, Y.; Matsunaga, S.; Tokuda, H.; Nishino, H. New abietane diterpenoids from the cones of Larix kaempferi. Can. J. Chem. 2000, 78, 31-40. [CrossRef]

59. Barrero, A.F.; Sanchez, J.F.; Alvarez-Manzaneda, E.J.R.; Dorado, M.M.; Haidour, A. Endoperoxide diterpenoids and other constituents from Abies marocana. Phytochemistry 1991, 30, 593-597. [CrossRef]

60. Feng, T.; Cai, X.-H.; Tan, Q.-G.; Luo, X.-D. Abietane diterpenoids and a lignin from Pinus yunnanensis. Z. Naturforsch. 2010, 2010, 765-769. [CrossRef]

61. Kitajima, J.; Noda, N.; Ida, Y.; Komori, T.; Kawasaki, T. Studies on the constituents of the crude drug "Fritillariae Bulbus." IV. On the diterpenoid constituents of the crude drug "Fritillariae Bulbus". Chem. Pharm. Bull. 1982, 30, 3922-3931. [CrossRef]

62. Fukushima, J.; Yatagai, M.; Ohira, T. Abietane-type and labdane-type diterpenoids from the cones of Chamaecyparis obtuse. J. Wood. Sci. 2002, 48, 326-330. [CrossRef]

63. Du, J.; Wang, M.-L.; Chen, R.-Y.; Yu, D.-Q. Two new bislabdane-type diterpenoids and three new diterpenoids from the roots of Cunninghamia lanceolata. Planta Med. 2001, 67, 542-547. [CrossRef]

64. Bohlmann, F.; Czerson, H. Neue labdan- und pimaren-derivate aus Palafoxia rosea. Phytochemistry 1979, 18, 115-118. [CrossRef]

65. Bohlmann, F.; Adler, A.; King, R.M.; Robinson, H. Ent-labdanes from Mikania alvimii. Phytochemistry 1982, 21, 173-176. [CrossRef]

66. Moon, C.; Kwak, J.H.; Kim, Y.B.; Jeon, Y.Y.; Lee, H.J. A composition comprising the extract of pine tree leaf or the compounds isolated therefrom for the prevention and treatment of cancer disease by inhibiting HPV virus and the uses thereby. U.S. Patent Application No. 14/366,093, 5 December 2013.

67. Zhang, Y.-S.; Zhang, Q.-Y.; Wang, B.; Li, L.-Y.; Zhao, Y.-Y. Chemical constituents from Ampelopsis grossedentata. J. Chin. Pharm. 2006, 15, 211-214.

68. Yue, R.; Li, B.; Shen, Y.; Zeng, H.; Li, B.; Yuan, H.; He, Y.; Shan, L.; Zhang, W. 6-C-methyl flavonoids isolated from Pinus densata inhibit the proliferation and promote the apoptosis of the HL-60 human promyelocytic leukaemia cell line. Planta Med. 2013, 79, 1024-1030. [CrossRef] [PubMed]

69. Abou-Zaid, M.; Dumas, M.; Chauret, D.; Watson, A.; Thompson, D. C-methyl flavonols from the fungus Colletotrichum dematium f.sp. epilobii. Phytochemistry 1997, 45, 957-961. [CrossRef]

70. Lin, S.; Zhang, Y.; Liu, M.; Yang, S.; Gan, M.; Zi, J.; Song, W.; Fan, X.; Wang, S.; Liu, Y.; et al. Abietane and C20-norabietane diterpenes from the stem bark of Fraxinus sieboldiana and their biological activities. J. Nat. Prod. 2010, 73, 1914-1921. [CrossRef]

71. Hirata, A.; Kim, S.Y.; Kobayakawa, N.; Tanaka, N.; Kashiwada, Y. Miltiorins A-D, diterpenes from radix Salviae miltiorrhizae. Fitoterapia 2015, 102, 49-55. [CrossRef]

72. Li, J.-C.; Zhang, Z.-J.; Yang, T.; Jiang, M.-Y.; Liu, D.; Li, H.-M.; Li, R.-T. Six new ent-abietane-type diterpenoids from the stem bark of Euphorbia neriifolia. Phytochem. Lett. 2019, 34, 13-17. [CrossRef]

73. Liu, A.-L.; Wang, H.-D.; Lee, S.M.; Wang, Y.-T.; Du, G.-H. Structure-activity relationship of flavonoids as influenza virus neuraminidase inhibitors and their in vitro anti-viral activities. Bioorg. Med. Chem. 2008, 16, 7141-7147. [CrossRef]

74. Moscona, A. Neuraminidase inhibitors of influenza. N. Engl. J. Med. 2005, 353, 1363-1373. [CrossRef] 
75. Han, Q.; Chang, C.; Li, L.; Klenk, C.; Cheng, J.; Chen, Y.; Xia, N.; Shu, Y.; Chen, Z.; Gabriel, G.; et al. Sumoylation of influenza A virus nucleoprotein is essential for intracellular trafficking and virus growth. J. Virol. 2014, 88, 9379-9390. [CrossRef]

76. Liao, T.-L.; Wu, C.-Y.; Su, W.-C.; Jeng, K.-S.; Lai, M.M.C. Ubiquitination and deubiquitination of NP protein regulates influenza A virus RNA replication. EMBO J. 2010, 29, 3879-3890. [CrossRef] [PubMed]

77. Cianci, C.; Gerritz, S.W.; Deminie, C.; Krystal, M. Influenza nucleoprotein: Promising target for antiviral chemotherapy. Antivir. Chem. Chemother. 2012, 23, 77-91. [CrossRef] [PubMed]

78. Dou, D.; Revol, R.; Östbye, H.; Wang, H.; Daniels, R. Influenza A virus cell entry, replication, virion assembly and movement. Front. Immunol. 2018, 9, 1581. [CrossRef] [PubMed]

79. Guilligay, D.; Tarendeau, F.; Resa-Infante, T.; Coloma, R.; Crepin, T.; Sehr, P.; Lewis, J.; Ruigrok, R.W.; Ortin, J.; Hart, D.J.; et al. The structural basis for cap binding by influenza virus polymerase subunit PB2. Nat. Struct. Mol. Biol. 2008, 15, 500-506. [CrossRef]

80. Dias, A.; Bouvier, D.; Crépin, T.; McCarthy, A.A.; Hart, D.J.; Baudin, F.; Cusack, S.; Ruigrok, R.W. The cap-snatching endonuclease of influenza virus polymerase resides in the PA subunit. Nature 2009, 458, 914-918. [CrossRef]

81. Herold, S.; Becker, C.; Ridge, K.M.; Budinger, G.R. Influenza virus-induced lung injury: Pathogenesis and implications for treatment. Eur. Respir. J. 2015, 45, 1463-1478. [CrossRef]

82. Julkunen, I.; Melén, K.; Nyqvist, M.; Pirhonen, J.; Sareneva, T.; Matikainen, S. Inflammatory responses in influenza a virus infection. Vaccine 2000, 19, S32-S37. [CrossRef]

83. Peiris, J.S.M.; Hui, K.P.Y.; Yen, H.-L. Host response to Influenza virus: Protection versus immunopathology. Curr. Opin. Immunol. 2010, 22, 475-481. [CrossRef]

(C) 2020 by the authors. Licensee MDPI, Basel, Switzerland. This article is an open access article distributed under the terms and conditions of the Creative Commons Attribution (CC BY) license (http://creativecommons.org/licenses/by/4.0/). 